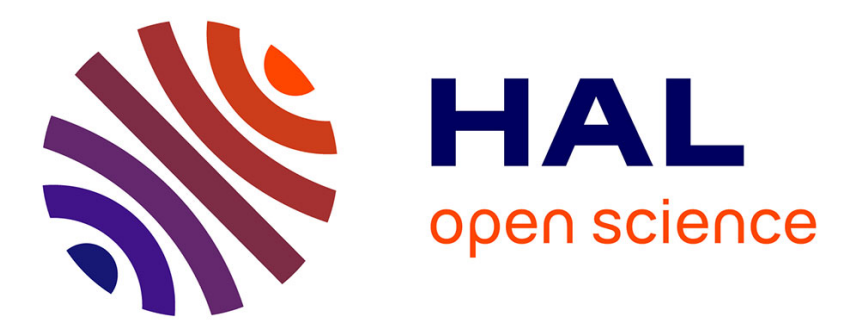

\title{
MSWI bottom ash used as basement at two pilot-scale roads: Comparison of leachate chemistry and reactive transport modeling
}

Laurent de Windt, David Dabo, Sofia Lidelöw, Rabia Badreddine, Anders Lagerkvist

\section{To cite this version:}

Laurent de Windt, David Dabo, Sofia Lidelöw, Rabia Badreddine, Anders Lagerkvist. MSWI bottom ash used as basement at two pilot-scale roads: Comparison of leachate chemistry and reactive transport modeling. Waste Management, 2011, 31, pp.267-280. 10.1016/j.wasman.2010.06.002 . hal-00545199

HAL Id: hal-00545199

https://hal-mines-paristech.archives-ouvertes.fr/hal-00545199

Submitted on 22 Dec 2010

HAL is a multi-disciplinary open access archive for the deposit and dissemination of scientific research documents, whether they are published or not. The documents may come from teaching and research institutions in France or abroad, or from public or private research centers.
L'archive ouverte pluridisciplinaire HAL, est destinée au dépôt et à la diffusion de documents scientifiques de niveau recherche, publiés ou non, émanant des établissements d'enseignement et de recherche français ou étrangers, des laboratoires publics ou privés. 
MSWI bottom ash used as basement at two pilot-scale roads: comparison of leachate chemistry and reactive transport modeling

Laurent De Windt ${ }^{\mathrm{a},{ }^{*}}$, David Dabo $^{\mathrm{a}, \mathrm{b}}$, Sofia Lidelöw ${ }^{\mathrm{c}}$, Rabia Badreddine ${ }^{\mathrm{b}}$, Anders Lagerkvist ${ }^{\mathrm{c}}$

${ }^{\text {a }}$ Ecole des Mines de Paris - Mines ParisTech, Geosciences Dept., 77305 Fontainebleau Cédex, France.

${ }^{\mathrm{b}}$ INERIS, Wastes and Contaminated Sites Unit, 60550 Verneuil-en-Halatte, France.

${ }^{\mathrm{c}}$ Luleå University of Technology, Division of Waste Science and Technology, SE-971 87

Luleå, Sweden.

* Corresponding author: laurent.dewindt@mines-paristech.fr, phone: +33-1-64.69.49.42, fax:

+33-1-64.69.47.13, Ecole des Mines de Paris, Geosciences Dept., 35 Rue St-Honoré, 77305

Fontainebleau Cédex, France. 


\begin{abstract}
The recycling of municipal solid waste incineration bottom ash as aggregates for road basement requires assessing the long-term evolution of leachate chemistry. The Dåva (Sweden) and Hérouville (France) pilot-scale roads were monitored during 6 and 10 years, respectively. Calculated saturation indices were combined to batch test modeling to set a simplified geochemical model of the bottom ash materials. A common reactive transport model was then applied to both sites. At Hérouville, $\mathrm{pH}$ and the concentration of most elements quickly drop during the first two years to reach a set of minimum values over 10 years. The decrease is less pronounced at Dåva. The evolution of $\mathrm{pH}$ and major element concentrations are fairly well related to the following $\mathrm{pH}$-buffering sequence: portlandite, $\mathrm{C}$ S-H phases or pseudo-wollastonite and, finally, calcite in equilibrium with atmospheric $\mathrm{CO}_{2}$. $\mathrm{Al}(\mathrm{OH})_{3}$, barite, ettringite and monohydrocalcite may also control leachate chemistry. $\mathrm{Cu}$ release is correctly modeled by DOM complexation and tenorite equilibrium. Temperature has no significant effect on the modeling of leachate chemistry in the range $5-30{ }^{\circ} \mathrm{C}$, except at high $\mathrm{pH}$. Effects at road edges and roadside slopes are important for the release of the less reactive elements and, possibly, for carbonation processes.
\end{abstract}

\title{
Keywords
}

bottom ash, environmental impact, geochemical modeling, trace metal, waste recycling 


\section{Introduction}

The recycling of municipal solid waste incineration bottom ash (MSWI BA), as aggregates for road and car-park construction, may impact the environment - both soil and water resources - by releasing salts and heavy metals into the leachates (e.g. Kosson et al., 1996). Therefore, characterizing the long-term evolution of the leachate chemistry is an important facet of the environmental impact assessment of such reuse scenarios. Recently, in complement to a large body of data acquired with batch and column tests, a few reliable field data have been acquired in large scale experiments for several years (Åberg et al., 2006; Flyhammar and Bendz, 2006; Hjelmar et al., 2007; Lidelöw and Lagerkvist, 2007; Dabo et al., 2009). The intrinsic mineralogical heterogeneity of MSWI BA, as well as the variability in the climatic events, especially the rainwater infiltration regime, complicates the interpretation of leachate chemistry.

Several geochemical modeling studies have been published to interpret leachate evolution from MSWI BA submitted to batch and column lab tests (e.g. Meima and Comans, 1997; Park and Batchelor, 2002; Astrup et al., 2006; Dijkstra et al., 2008; Hyks et al., 2009). By contrast, only a few modeling studies have been devoted to MSWI BA weathering occurring at pilot-scale applications, either in lysimeter cell (Guyonnet et al., 2008; Mostbauer and Lechner, 2006) or landfill (Johnson et al., 1999; Baranger et al., 2002). However, such situations substantially differ from a road basement configuration. Edge effects that are typical of road structures cannot be correctly reproduced for instance. To the authors' knowledge, only Apul et al. (2007) developed a reactive transport model relevant for road basements but the complexity of the chemical processes have been simplified to a set of $\mathrm{K}_{\mathrm{d}}$ parameters.

This paper aims at presenting the results of modeling of leachate from two pilot-scale road basements containing MSWI BA: the Dåva site in Sweden (Lidelöw and Lagerkvist, 
2007) and the Hérouville site in France (Dabo et al., 2009), monitored for 6 and 10 years, respectively. The comparison of these two sites that were developed independently helps to shed light on common processes, but also discrepancies, in view of rationalizing leachate emission. In the first part of the paper, calculated saturation indices and solubility diagrams are combined to batch test modeling to set a simplified geochemical model of the two bottom ash materials. The second part of this paper attempts to develop a reactive transport model applicable to field conditions. A reactive transport model can help to identify and discriminate between the main hydrodynamic and geochemical processes and can be an useful tool for environmental impact assessments. The $\mathrm{pH}$-buffering processes, and their effect on the evolution of leachate chemistry (major elements and trace metals) over time, are more particularly investigated.

\section{Pilot-site configuration, material properties and batch tests}

\subsection{Configuration of the pilot-sites}

The Dåva experimental road was built during the summer of 2001 at the Dåva power plant in Umeå (Sweden) and was used mainly by trucks for transport of incineration residues. Fig. 1 provides for schematic representation of the site. The road is $7 \mathrm{~m}$ wide and $80 \mathrm{~m}$ long. A 0.4 $\mathrm{m}$ thick subbase layer of MSWI BA is covered by a $15 \mathrm{~cm}$ base layer of rock crushed rock (gravel) and a $10 \mathrm{~cm}$ thick asphalt layer. Uncovered roadside slopes were built with the same bottom ash without being covered by asphalt. The average yearly precipitation in the area was about $600 \mathrm{~mm}$ per year during the sampling period, of which $40-50 \%$ falls as snow.

The Hérouville test road was built in 1997 in the Parisian Region (France) and characterized by a low traffic, about 10 vehicles per day. As schematically shown in Fig. 1, the road is $4 \mathrm{~m}$ wide and $20 \mathrm{~m}$ long and contains a $25 \mathrm{~cm}$ thick subbase layer of MSWI BA covered by a $15 \mathrm{~cm}$ thick asphalt cover. A polyethylene drainage liner (geomembrane) is 
located at the bottom of the subbase layer. The road is fully embedded in a cultivated loamy and sandy soil. The depth of the local aquifer varies seasonally, between 3 and $7 \mathrm{~m}$ beneath the road. The local average precipitation rate was about $700 \mathrm{~mm} / \mathrm{y}$ for the 1998-2008 period. There was an initial leachate production due to discharge by gravity during the very first weeks. Next, leachate volume was fairly well correlated to local precipitation in terms of intensity and frequency (Dabo et al., 2009). Leachate production was most probably linked to preferential flows since the geomembrane did not completely cover the road sides or edges, allowing lateral water infiltration into the subbase layer.

The methodology of leachate monitoring and sampling are presented into details in Lidelöw and Lagerkvist (2007) for the Dåva site and in Dabo et al. (2009) for the Hérouville site. The Hérouville road was monitored in two stages, from 1997 to 2000, and then again in 2007 to evaluate leachate chemistry after 10 years of utilization. MSWI BA samples were also collected by drilling after 10 years in the road subbase at Hérouville.

\section{[FIGURE 1]}

\subsection{MSWI bottom ashes}

The Swedish MSWI BA originated from the Dåva power plant in Umeå (Sweden). The plant was mainly fueled with MSW and small fractions of sorted industrial wastes such as wood, rubber and plastic. The bottom ash was screened to remove magnetic material and particles greater than $50 \mathrm{~mm}$, and then weathered outdoor in heaps for 6 months. Compared with composition ranges of MSWI BA (Jeong et al., 2005), the material contained relatively large amounts of $\mathrm{Cu}$ and $\mathrm{Zn}$, but small amounts of $\mathrm{Al}$.

The French MSWI BA came from a municipal waste incineration facility located in the Parisian Region. Compared to the Swedish ash, metallic aluminum was also removed 
from the bottom ash in addition to magnetic materials and the storage was shorter $(<3$ months) corresponding to a lower stage of MSWI BA maturation. Compared with others MSWI BA (Jeong et al., 2005), the French bottom ash had relatively large amounts of Al and heavy metals $\mathrm{Cu}, \mathrm{Pb}$ and $\mathrm{Zn}$ but relatively low contents of $\mathrm{As}, \mathrm{Cd}$ and $\mathrm{Hg}$.

\subsection{Batch leaching tests}

The model of the initial mineralogy of MSWI BA was partly derived from a set of batch leaching tests. A compliance test was applied to the Dåva bottom ash, consisting in a twostage batch test at L/S 2 for $6 \mathrm{~h}$ and subsequently L/S 8 for $18 \mathrm{~h}$ according to the European standard EN 12457-3. Prior to the test, the samples were crushed and sieved to a particle size $95 \mathrm{wt} \%<4 \mathrm{~mm}$. Contrarily to the standard test, the MSWI bottom ash of the Hérouville site was neither crushed nor dried to prevent as much as possible any chemical artifacts. The L/S ratio ranged from 1 to 100 . The batch tests were performed during $48 \mathrm{~h}$ with distilled water in an airtight device, to avoid carbonation, under permanent agitation. Distilled water was used as a leachant, i.e., the leaching $\mathrm{pH}$ was dictated by the material itself. The leaching tests of Hérouville were made in 2008 and that, therefore, the MSWI bottom ash did not strictly correspond to the material used for the test road construction in 1997. However, both bottom ashes came from the same incineration facility without any significant change in the bottom ash production but a slight evolution of municipal waste sorting.

\section{Modeling approach and data}

\subsection{Reactive transport code and thermodynamic database}

All the calculations were done with the reactive transport code HYTEC (van der Lee et al., 2003 ) that couples advective and diffusive transport of solutes to chemical reactions. The flow and transport module was based on the representative elementary volume (REV) 
approach with finite volume calculation. The Davies model was used for activity correction with an ionic strength limit of $0.5 \mathrm{~mol} / \mathrm{L}$.

The MINTEQ thermodynamic database (version 3.12, Allison et al., 1990) was selected and enriched with additional data for cement phases, as reported in Table 1. Calcium silicate hydrate $(\mathrm{C}-\mathrm{S}-\mathrm{H})$ phases formed during weathering of bottom ash are usually poorly crystallized phases (Speiser et al., 2000). The saturation indices was calculated for both crystalline and amorphous C-S-H phases. The former were nevertheless used in the calculations because their formation constants were known at different temperatures, which allowed for analyzing temperature dependency in the range $5-30{ }^{\circ} \mathrm{C}$. The solid $\mathrm{Pb}(\mathrm{OH})_{2}$ was considered as a simplified formulation of more complex hydrous phases formed at alkaline pH (see De Windt and Badreddine, 2007).

The dissolved organic matter (DOM) of MSWI BA is known to have a strong affinity for $\mathrm{Cu}$. A simple model was used to simulate the complexation process. Fulvic acids were assumed to be the responsible ligands for $\mathrm{Cu}$-binding and to constitute $15 \mathrm{wt} . \%$ of the measured dissolved organic carbon (DOC), according to van Zoemeren and Comans (2004). Since there is no specific model for metal-fulvic interaction implemented in HYTEC, EDTA (ethylene-diamine-tetra-acetic acid) was considered as a substitute for the fulvic fraction. This molecule, that holds carboxylic acid functional groups as fulvics, is also a strong $\mathrm{Cu}$ complexant. The thermodynamic constants for EDTA acid/base properties and $\mathrm{Cu}$ complexation were taken from the MINTEQ database.

$$
\text { [TABLE 1] }
$$

\subsection{Solubility controlled modeling}

One of the major difficulties encountered in the modeling of MSWI BA chemical reactivity is their wide-ranging mineralogical composition. They are composed of quenched glass and 
relic glass (about $50 \%$ by weight), native metals ( $\mathrm{Al}, \mathrm{Fe}$ ) and a broad spectra of minerals such as silicates (e.g. feldspars, gehlenite, pseudo-wollastonite, quartz), carbonates (e.g. calcite), sulfates (e.g. ettringite, gypsum), aluminum and iron (hydr)oxides (e.g. gibbsite, magnetite). Furthermore, a given trace element is distributed among several solid phases. A second reason of modeling complexity is that many primary minerals formed during combustion, as well as glassy phases formed during quenching, remain permanently under-saturated (i.e. thermodynamically not stable) under meteoric weathering conditions. For instance, gehlenite was found to be strongly under-saturated with respect to leachate whatever the $\mathrm{pH}$ (section 4.2). Therefore, modeling their long-term evolution requires kinetic parameters (e.g. intrinsic rate constant, specific surface distribution) that are specific to each type of phases and are generally unknown.

One way to (partially) manage this modeling complexity is to only consider those minerals characterized by fast kinetics of reaction (e.g. calcite, C-S-H, ettringite, portlandite) that have been identified in the abundant literature on MSWI BA. These minerals are usually the by-products of the hydrolysis of the primary oxides formed during waste combustion. The dissolution and precipitation of the selected solid phases, characterized by fast kinetics, were assumed to be at thermodynamic equilibrium in the subbase layers. However, as discussed throughout the paper, the control of leachate chemistry by the primary phase pseudowollastonite was also considered as a modeling option. Kinetic rate constants were published for wollastonite under alkaline $\mathrm{pH}$ conditions (Golubev et al., 2006). The mean data is about $10^{-9} \mathrm{~mol} / \mathrm{m}^{2} / \mathrm{s}$ at $25^{\circ} \mathrm{C}$. Kinetics required to estimate reactive surfaces, but this probably neither corresponds to a fast or to a slow kinetics of dissolution at the time scale of interest (from day to week). By simplicity, thermodynamic equilibrium was also assumed for pseudowollastonite in the model. 
A second and complementary modeling approach is to consider that the solubility of trace metals is also controlled by secondary phases without explicitly considering the dissolution of primary source-terms. Mineral depletion of trace elements, after which sorption processes would take over, is assumed not to take place within the time frame of the measurements. Solubility control by secondary phases is a common fact in natural environment and has been experimentally demonstrated in the field of MSWI BA (e.g. Piantone et al., 2004). The solubility controlling phase usually varies according to the solution chemistry (e.g. hydroxides at high $\mathrm{pH}$ vs. carbonates at neutral $\mathrm{pH}$ ). Sorption on $\mathrm{Al}$ and $\mathrm{Fe}$ oxyhydroxides is another important controlling process for trace metals. However, this mechanism was not considered in the present study since the trace element concentrations were systematically fixed by one or several secondary minerals. In principle, trace element concentrations are over-estimated in a solubility-controlled approach based on pure phases. Taking into account sorption processes or solid solution formation would decrease the calculated concentrations.

\subsection{Flow and transport parameters}

The main objective of the pilot-sites was leachate sampling and the hydrodynamic properties of the road components were relatively poorly characterized. Only the hydraulic conductivity at water saturation of the ten-year old bottom ash was estimated at Hérouville after removal of the asphalt cover $\left(\mathrm{K}_{\mathrm{sat}} \sim 5 \times 10^{-6} \mathrm{~m} / \mathrm{s}\right)$. The same value was assumed for the Dåva bottom ash. The hydraulic conductivities of the sandy and gravel materials were taken from the literature (Guymon, 1994). The hydraulic conductivities of the asphalt covers (i.e. runoff on the pavement vs. infiltration) were then adjusted (Table 2) to fit the chloride release profiles, in the roadside slope and under the asphalt pavement, assuming that precipitations were distributed evenly over the year. Differences between the horizontal and vertical hydraulic 
conductivity were neglected for all the layers of the road base. The presence of preferential flow paths within the subbase layer was not investigated. However, the asphalt cover of the Dåva and Hérouville roads did not present any effective cracks after 6 and 10 years, respectively. The preferential flow pathway along the geomembrane observed in the Hérouville pilot-site was simulated by setting a higher hydraulic conductivity at the bottom of the MSWI BA subbase. The calculations were performed under water saturated conditions. A detailed unsaturated modeling linked to daily precipitation data was more costly in terms of computer time and could not be compared to site data since the leachates were sampled every two weeks only.

\author{
[TABLE 2]
}

\title{
4. Mineralogical model of the MSWI bottom ash
}

The geochemical model of the MSWI BA was built on taking into account: i) ash mineralogy, determined on the basis of both mineralogical analysis (XRD and SEM) of the Hérouville ash (Dabo et al., 2009) and literature review, ii) calculated saturation indices for Dåva and Hérouville field leachates, and iii) batch test modeling.

\subsection{Brief literature review of solubility controlling minerals}

According to the literature (Johnson et al., 1999; Meima and Comans, 1999; Dijkstra et al., 2008), there are three main sequences controlling the leachate concentrations in major elements during MSWI BA weathering: i) portlandite and gypsum for fresh unweathered bottom ash with leachate $\mathrm{pH}$ greater than 12 , ii) ettringite, gibbsite and gypsum for quenched bottom ash with $\mathrm{pH}$ close to 10.5 , and iii) calcite in equilibrium with atmospheric carbon dioxide $\left(\mathrm{CO}_{2}\right)$ for carbonated bottom ash with $\mathrm{pH}$ close to 8 (the mineral formulae can be 
found in Table 1). It is likely that other cement-type phases are also active with respect to $\mathrm{pH}$ in the range $10.5-12$. Thaumasite can contribute to $\mathrm{pH}$-buffering at $\mathrm{pH}$ around 10 (Mostbauer and Lechner, 2006). However, this phase is generally present at a low content in MSWI BA compared to other sulfates like gypsum or ettringite (Piantone et al., 2004). Friedel'salt (equivalent to hydrocalumite) represents the $\mathrm{Cl}$ pole of the AFm cement-type phases. Its high molar content in hydroxyl ions could buffer the $\mathrm{pH}$ of leachate in the alkaline domain. The potential role of $\mathrm{C}-\mathrm{S}-\mathrm{H}$ in the alkaline $\mathrm{pH}$ range is mentioned by several authors (Johnson et al., 1999; Speiser et al., 2000; Piantone et al., 2004). Regarding the primary phases, wollastonite is the most likely to control Si concentration. For instance, Bodénan et al. (2010) indicated that leachate of boiler ash from a MSW fluidized-bed incinerator was close to thermodynamic equilibrium with this phase. This controlling process was assessed as an option of the mineralogical model of bottom ash. Pseudo-Wollastonite, its low pressure polymorph, was considered to be more representative of the solid formation during incineration.

\subsection{Saturation indices of leachates}

Some insights into the chemical processes occurring in the two pilot-scale roads were investigated with the geochemical module of HYTEC (named CHESS) by calculating saturation index (SI) of leachate with respect to primary and secondary minerals as well as by comparing field data with stability domains of Al-SO $\mathrm{SO}_{4}$ minerals. Due to uncertainties, leachate is assumed to be in thermodynamic equilibrium with respect to a given mineral if the SI of this mineral ranges between -0.5 and $0.5 \log$ unit. A positive SI (super-saturation or oversaturation state) indicates that the given mineral may precipitate as a secondary mineral. A negative SI (under-saturation state) indicates that the given mineral is not stable with respect to leachate chemistry and may dissolve provided the mineral is effectively present in the 
material. Table 3 tabulates SI calculated for a selection of representative leachates. The selected data are denoted by square symbols in Figs. 5-6-7-9 that report the evolution with time of major and trace element concentrations in the leachates (discussed in Section 5). At both sites, the $\mathrm{pH}$ of the selected leachates decreases with time. Their temperatures are around $18{ }^{\circ} \mathrm{C}$ at Hérouville and range from 8 to $24{ }^{\circ} \mathrm{C}$ at Dåva.

Gehlenite, pseudo-wollastonite and quartz are all primary minerals of MSWI bottom ash. Gehlenite is systematically not stable (under-saturated) with respect to all leachates. Pseudo-wollastonite is slightly supersaturated at alkaline $\mathrm{pH}$ but under-saturated (i.e. thermodynamically unstable) at neutral $\mathrm{pH}$. The opposite is true for quartz. At neutral $\mathrm{pH}$, leachates are not far from equilibrium with quartz (and slightly under-saturated with respect to chalcedony that is most likely to precipitate at low temperature).

Portlandite is close to equilibrium or the saturation point $(\mathrm{SI}=-0.3)$ with respect to the very early leachates at Hérouville, which is consistent with the highest $\mathrm{pH}$ measured on site $(\mathrm{pH}=12.4)$. In the very first months, the SI of Friedel'salt are supersaturated with respect to the alkaline and Cl-enriched leachates. As indicated by strongly negative SI, it becomes quickly unstable (among others, due to $\mathrm{Cl}$ leaching) and should dissolve. The SI of ettringite are positive at $\mathrm{pH} \geq 11$, but strongly negative below $\mathrm{pH} 10$. Ettringite precipitation is therefore likely during the first years, whereas dissolution should occur on the long term. Thaumasite can precipitate from the early alkaline leachates of Hérouville (SI 3) but not at moderately alkaline to neutral $\mathrm{pH}$. At Hérouville, all the C-S-H phases, either crystalline or amorphous, are clearly close to equilibrium at alkaline $\mathrm{pH}$ but strongly under-saturated at slightly alkaline to neutral $\mathrm{pH}$. The higher the $\mathrm{pH}$ is, the higher the $\mathrm{Ca} / \mathrm{Si}$ is. $\mathrm{C}-\mathrm{S}-\mathrm{H} 1.8$ and 1.1 are supersaturated at $\mathrm{pH} 12.4$, but only $\mathrm{C}-\mathrm{S}-\mathrm{H} 1.1$ at $\mathrm{pH} 11.4$. Tobermorite $(\mathrm{Ca} / \mathrm{Si}=0.8)$ is the only stable phase at $\mathrm{pH}$ 11.4. All C-S-H phases are significantly under-saturated at neutral $\mathrm{pH}$ conditions. 
Gypsum is always under-saturated with respect to leachates, whatever the $\mathrm{pH}$ or temperature. At Hérouville, amorphous $\mathrm{Al}(\mathrm{OH})_{3}$ and gibbsite are clearly under-saturated in the alkaline $\mathrm{pH}$ range $12.5-10.5$ whereas the former is not far from equilibrium at neutral $\mathrm{pH}$. At Dåva, gibbsite is supersaturated at all $\mathrm{pH}$ values while amorphous $\mathrm{Al}(\mathrm{OH})_{3}$ is not far from equilibrium at $\mathrm{pH} \leq 10.5$. Calcite is close to saturation in the long term leachate of Hérouville $(\mathrm{pH} \sim 8)$ while systematically supersaturated $(\mathrm{SI} \sim 1)$ in any other leachates, especially at alkaline $\mathrm{pH}$. The same conclusion have been recently drawn for alkaline leachates of a boiler ash from a MSW fluidized-bed incinerator (Bodénan et al., 2010).

At Dåva, barite is systematically close to equilibrium whatever the $\mathrm{pH}$ and temperature (whereas witherite is always under-saturated). Tenorite is supersaturated at alkaline $\mathrm{pH}$ and close to equilibrium (Hérouville) or under-saturated (Dåva) on the long term. $\mathrm{Cu}$-hydroxide is close to equilibrium at $\mathrm{pH} \sim 11$. The interaction between $\mathrm{Cu}$ and dissolved organic matter (DOM) was not taken into account in these SI calculations. The leachates are under-saturated with respect to any secondary $\mathrm{Pb}$ phases, whatever the $\mathrm{pH}$, temperature or time; especially at Dåva. For instance, the leachate are significantly under-saturated with respect to cerussite $(\mathrm{SI} \leq 2)$ and hydrocerussite $(\mathrm{SI} \leq 7)$, in agreement with the study of Mostbauer and Lechner (2006). Pb-hydroxide makes exception since it is close to equilibrium in the alkaline domain during the first year.

\section{[TABLE 3]}

\subsection{Plot of $\mathrm{Al}$ and $\mathrm{SO}_{4}$ solubility diagrams}

Plotting the leachate data on calculated $\mathrm{Al}$ and $\mathrm{SO}_{4}$ solubility diagrams is a complementary tool for data analyzing. The diagrams were built with CHESS and the present database, for chemical conditions representative of leachate. Despite a recurrent under-saturation state, amorphous $\mathrm{Al}(\mathrm{OH})_{3}$ formation is relatively well corroborated by the plot of field data on the 
Al solubility diagram (Fig. 2). In particular, Al concentration is strongly correlated to $\mathrm{pH}$ in the range $10-6$. It is worth noting that the Dåva field data match the ettringite solubility limits in both $\mathrm{Al}$ and $\mathrm{SO}_{4}$ solubility diagrams fairly well. In agreement with SI calculation, the $\mathrm{SO}_{4}$ field data are systematically below the gypsum solubility limit.

\section{[FIGURE 2]}

\subsection{Batch test modeling and initial mineralogy}

Fig. 3 shows the experimental and modeling data of batch tests applied to the Hérouville and Dåva MSWI bottom ashes. The mineralogical model was mainly derived from the tests related to the Hérouville ash. The evolution of $\mathrm{pH}$ with $\mathrm{L} / \mathrm{S}$ is well reproduced by modeling (Fig. 3a). A few amount of portlandite was introduced in the initial mineralogy to simulate the highest $\mathrm{pH}$ values. C-S-H phases were then taken into account to model the subsequent evolution of $\mathrm{pH}$ and $\mathrm{Ca}$ concentration. In cement chemistry, to given $\mathrm{pH}$ of solution corresponds a given $\mathrm{Ca} / \mathrm{Si}$ ratio of C-S-H (e.g. Blanc et al., 2010). Hillebrandite $(\mathrm{Ca} / \mathrm{Si}=2.0)$ was considered in the present case. Results of similar quality were, however, obtained when pseudo-wollastonite was substituted to hillebrandite. The normalized release $\mathrm{Cl}$ data are perfectly in a (horizontal) line, both experimentally and in the modeling (Fig. 3b). This is indicative of a conservative behavior or, equivalently, that pore water is the main source of $\mathrm{Cl}$. On the opposite, the evolution of $\mathrm{Ca}$ and $\mathrm{SO}_{4}$ release with $\mathrm{L} / \mathrm{S}$ are representative of solubility controlling processes. The model fairly well simulates Ca release with L/S increase. For $\mathrm{SO}_{4}$, the experiment/model agreement is satisfactory at $\mathrm{L} / \mathrm{S}=5,10$ and 100 but fail to simulate the lowest L/S. Considering a small amount of gypsum improved the modeling. In order to reduce the number of fitted parameters, the modeling of DOM release behavior was also derived from batch test data (available for Hérouville only). As shown in Fig. 3b, the experimental values of COT slightly increases with L/S. COT release is thus not 
fully conservative. Nevertheless, in a first approximation, pore water was assumed to the single source of DOM in the model. This initial value was derived from the batch test at $\mathrm{L} / \mathrm{S}=$ 1 , the most relevant for $\mathrm{L} / \mathrm{S}$ in the basement $(\mathrm{L} / \mathrm{S} \sim 0.2)$. The agreement between the measured and calculated leached $\mathrm{Cu}$ at $\mathrm{L} / \mathrm{S}=10$ is also clearly improved while considering $\mathrm{Cu}-\mathrm{DOM}$ interactions (Fig. 3c); which "validates" the EDTA approximation discussed in Section 3.1. Fig. $3 \mathrm{c}$ shows the full batch data set at $\mathrm{L} / \mathrm{S}=10$. Beside $\mathrm{Cl}$ and $\mathrm{pH}$, which were adjusted to batch data, the model correctly matches the experimental data (Al excepted, with an underestimation of two orders of magnitude).

Table 4 gives the proportions in the raw MSWI BA of the reactive minerals of interest for the modeling. As discussed, halite, sylvite and portlandite contents were quantitatively derived from batch leaching tests. The content in C-S-H phase, or pseudo-wollastonite as a second option, was derived from the $\mathrm{pH}$ evolution with increasing $\mathrm{L} / \mathrm{S}$. The contents in calcite, ettringite and quartz were semi-quantitatively estimated from XRD analyses. C-S-H phases are considered as modeling analogues to simulate the $\mathrm{pH}$ transient stage in the range $12-10.5$, though they themselves derived from the hydrolysis of primary alkaline phases. Trace metals were introduced as (hydr)oxide $(\mathrm{Cu}, \mathrm{Pb})$ at an arbitrary low content $(0.1 \%$ by weight) though high enough to ensure that mineral depletion of trace elements did not to take place within the modeled time frame. The other solid phases that could possibly precipitate during the modeling of the system evolution are written in bold in Table 3.

For the Dåva bottom ash, the compliance batch test at $\mathrm{L} / \mathrm{S}=10$ was only available. In a first approximation, the mineralogical set assumed for the Hérouville material was applied to the Dåva material. This makes sense for the potential secondary phases that may precipitate under the road conditions, which are not fundamentally different from the Hérouville site. This also partly justified for the initial mineralogy since MSWI BA described in the literature share many similarities. However, some specific adjustments were required. Firstly, halite and 
sylvite contents were directly derived from batch test. Secondly, at the higher stage of maturation of the Dåva bottom ash corresponds a lower $\mathrm{pH}(\mathrm{pH}=11$ instead of 12.3). This $\mathrm{pH}$ could be simulated assuming portlandite depletion and $\mathrm{C}-\mathrm{S}-\mathrm{H}$ of lower $\mathrm{Ca} / \mathrm{Si}$ ratios. The best $\mathrm{pH}$ adjustment was obtained with tobermorite, although $\mathrm{pH}$ was underestimated by 0.5 pH unit (Fig. 3d). The mineralogical model of the Dåva MSWI BA is given in Table 4. Globally, the modeling of the batch test is satisfactory for most elements (including Al); excepted $\mathrm{Pb}$ that is overestimated by two orders of magnitude (Fig. 3d).

[TABLE 4-FIGURE 3]

\section{Leachate evolution and reactive transport modeling}

\subsection{Flow field}

Fig. 1 shows the grids used in the reactive transport calculations and the location of the leachate collectors. A full cross section was required for modeling the Hérouville road due to the asymmetric location of the sampling system (at the right-hand side of the road), which generates a dissymmetric water flow. Half a cross section was sufficient for the symmetric Dåva road. The calculated water flow field is given in Fig. 4. At Dåva, the runoff at the surface of the pavement goes towards the ditch with a maximum water infiltration calculated for the uncovered slopes. This is in agreement with field measurement where the majority of leachate was produced in the roadside slopes. At Hérouville, modeling leads to runoff on the pavement and a moderate water infiltration at the road edges. The model also took into account the initial leachate production that occurred during the very first weeks due to water discharge by gravity. The infiltrated water at the road edges was further canalized by the geomembrane towards the collector. This artifact of the sampling system was correctly reproduced by the model. 


\subsection{Release of $\mathrm{Cl}, \mathrm{Na}$ and $\mathrm{DOC}$}

\section{Field data}

Fig. 5 shows the evolution with time of the leachante concentrations of $\mathrm{Cl}, \mathrm{Na}$ and $\mathrm{DOC}$ at the sampling points. At Hérouville, $\mathrm{Ca}$ and $\mathrm{Na}$ leachate concentrations are initially about 1000 $\mathrm{mg} / \mathrm{L}$ and progressively decrease over time to reach a mean value of $100 \mathrm{mg} / \mathrm{L}$ after 10 years. The initial values are higher at Dåva, around $10000 \mathrm{mg} / \mathrm{L}$. Data scattering is more pronounced at Hérouville. Edge effects are important for $\mathrm{Cl}$ and $\mathrm{Na}$ releases. While the asphalt cover is a barrier against rainwater percolation through the bottom ash layer, $\mathrm{Cl}$ and Na release is much more pronounced in the uncovered slopes at Dåva or driven by lateral inflows at Hérouville. Lateral inputs have been theoretically assumed to be a major source of leachate production by different authors (Kosson et al., 1996; Apul et al., 2007). The increase of $\mathrm{Cl}$ concentrations after 5 years in the roadside slope at Dåva may be due to engineering works performed during this period.

At Hérouville, DOC leachate concentrations are about $1000 \mathrm{mg} / \mathrm{L}$ the first month and rapidly decrease over time to reach a mean value of $10 \mathrm{mg} / \mathrm{L}$ after 10 years. DOC distribution is scattered. At Dåva, DOC leachate concentrations are about $100 \mathrm{mg} / \mathrm{L}$. The contrasted leaching between the roadside slope and under the pavement is noticeable, but field DOC concentrations decrease more slowly than the corresponding $\mathrm{Cl}$ and $\mathrm{Na}$ ones.

\section{Modeling}

Fig. 4 gives a 2D picture of the $\mathrm{Cl}$ plumes calculated after 3 years. $\mathrm{Cl}$ ions have been leached away at the edges and roadside slopes but preserved from leaching by the asphalt cover. The barrier effect of the geomembrane at Hérouville can also be noticed in the figure. Despite the simplified hydrodynamic modeling approach, the $\mathrm{Cl}$ field data are well fitted by the model 
(Fig. 5); supporting the modeling assumption that $\mathrm{Cl}$ was non reactive (conservative) and mainly present in the initial pore water. Diffusion inside the bottom ash layer below the pavement is combined to weak lateral flows. Na release is closely related to $\mathrm{Cl}$ release which is demonstrated by the very good agreement between the field data and calculated curve (fitted on the chloride content only). However, the molal ratio $\mathrm{Na} / \mathrm{Cl}$ that is initially close to unity increases over time progressively. This suggests another sources of $\mathrm{Na}$ release on the long-term, such as the slow dissolution of glassy particles.

In the modeling of the Hérouville site, the release of dissolved organic carbon (DOC) is similar to the release of dissolved chloride salts. The calculated data represent an upper limit to field data. Such an upper limit might validate the assumption that the main source of DOM is also the initial pore water of the MSWI bottom ash.

\section{[FIGURE 5]}

\subsection{Evolution of $p H$ with time}

\section{Field data}

Fig. 6 shows the $\mathrm{pH}$ field data plotted as a function of time. The $\mathrm{pH}$ values are significantly more scattered than $\mathrm{Cl}$ concentrations. However, at Hérouville, $\mathrm{pH}$ clearly decreases over the first three years, starting with very alkaline $\mathrm{pH}(>12)$, followed by an intermediate stage of moderately alkaline $\mathrm{pH}(11.5$ - 9.5), to reach a long-term $\mathrm{pH}$ value of about 7.5. At Dåva, $\mathrm{pH}$ remains within the range 11.5 - 10.5 during the first 4 years but eventually drops to 8 in the roadside slopes. The permanently high $\mathrm{pH}$ of the leachate beneath the asphalt cover demonstrates that carbonation was hampered by limited infiltration and gas exchange and that microbial production of $\mathrm{CO}_{2}$ can be neglected. Similarly, batch tests applied to ten-year old drilled core samples inside the subbase at Hérouville indicated that carbonation was still in progress (Dabo et al., 2009). A similar situation has also been reported in a 10-year old 
asphalt road with steel slag of electric arc furnace (Suer et al., 2009). The slag from the pavement edge showed traces of carbonation and leaching processes, whereas the road centre material was nearly identical to fresh slag, in spite of an accessible particle structure.

\section{Modeling}

The two driving forces for the long-term evolution of the bottom ash chemistry considered in this modeling study are: i) the transport of dissolved species by rainwater infiltration (mostly at the edges) as well as diffusion (mostly inside the subbase layer), as introduced in the discussion of $\mathrm{Cl}$ release, and ii) the neutralization of alkalinity by reaction with carbon dioxide $\left(\mathrm{CO}_{2}\right)$, which might have a strong effect on ash mineralogy and on the $\mathrm{pH}$ evolution of leachates. Diffusion of gaseous $\mathrm{CO}_{2}$ from the atmosphere into the road sides and basement can occur since the MSWI BA is not water saturated in reality. To a lesser extent, microbiological degradation (respiration) of the MSWI BA may also yield in situ production of $\mathrm{CO}_{2}$ (Rendek et al., 2006).

At Hérouville, a preliminary calculation indicates that $\mathrm{pH}$ would remain constantly high (Fig. 6, "no $\mathrm{CO}_{2}$ " legend), in contrast with field data, if dissolved $\mathrm{CO}_{2}$ in rainwater was considered as the only input of $\mathrm{CO}_{2}$. The same conclusion can be drawn from the comparison of Ca field data and modeling (Fig. 7, "no $\mathrm{CO}_{2}$ " legend). Since gaseous diffusion cannot be modeled by HYTEC, the carbonation process was simulated through a permanent input of $\mathrm{CO}_{2}$ to the system according to a zero order rate: $\mathrm{d}\left[\mathrm{CO}_{2}\right] / \mathrm{dt}=\mathrm{k}$. The rate constants $\mathrm{k}$ were adjusted to fit as best as possible the evolution of $\mathrm{pH}$ with time under Hérouville edge zones (which locations are specified in Fig. 1). Though a direct physical meaning cannot be assigned to this constant, the adjusted input rate was about $50 \mathrm{mmol} / \mathrm{dm}^{3} / \mathrm{y}$. The calculated $\mathrm{pH}$ profiles resulting from the progressive carbonation of MSWI BA is in better agreement with the field data. Note that the temperature of reference in the present discussion is $15^{\circ} \mathrm{C}$. 
Temperature effect is further discussed in Section 6. The calculated profile constitutes an upper envelop of field data. In the modeling, the $\mathrm{pH}$ is buffered around 12.5 by portlandite equilibrium during the first months of leachate emission while this mineral is progressively leached out and carbonated according to the following reaction:

$$
\text { portlandite }+\mathrm{H}_{2} \mathrm{CO}_{3} \rightarrow \text { calcite }+2 \mathrm{H}_{2} \mathrm{O}
$$

$\mathrm{H}_{2} \mathrm{CO}_{3}$ denotes the dissolved form of carbon dioxide. Decalcification of $\mathrm{C}-\mathrm{S}-\mathrm{H}$ of high $\mathrm{Ca} / \mathrm{Si}$ ratio takes place once portlandite is fully depleted, buffering the $\mathrm{pH}$ in the range $12-10.5$ :

$$
3 \text { hillebrandite }+3.5 \mathrm{H}_{2} \mathrm{CO}_{3} \rightarrow 3.5 \text { calcite }+0.5 \text { tobermorite }+4 \mathrm{H}_{2} \mathrm{O}
$$

An equivalent reaction can be associated to pseudo-wollastonite in the same $\mathrm{pH}$ domain:

$$
\mathrm{CaSiO}_{3}+\mathrm{H}_{2} \mathrm{CO}_{3} \rightarrow \text { calcite }+ \text { quartz }+\mathrm{H}_{2} \mathrm{O}
$$

In a third stage, the dissolution of C-S-H of low $\mathrm{Ca} / \mathrm{Si}$ ratio, and to a lower extent ettringite, keeps $\mathrm{pH}$ in the range 10.5-9.5:

$$
\begin{aligned}
& \text { tobermorite }+5 \mathrm{H}_{2} \mathrm{CO}_{3} \rightarrow 5 \text { calcite }+6 \text { quartz }+10 \mathrm{H}_{2} \mathrm{O} \\
& \text { ettringite }+3 \mathrm{H}_{2} \mathrm{CO}_{3} \rightarrow 3 \text { calcite }+3 \text { gypsum }+2 \mathrm{Al}(\mathrm{OH})_{3}(\mathrm{am})+26 \mathrm{H}_{2} \mathrm{O}
\end{aligned}
$$

These reactions seem to have been active at least during the first two years at the Hérouville pilot-site. On the long term, equilibrium of calcite with atmospheric $\mathrm{CO}_{2}$ pressure $\left(4 \times 10^{-4}\right.$ atm) buffers $\mathrm{pH}$ around 8 according to the following reaction:

$$
\text { calcite }+\mathrm{H}_{2} \mathrm{CO}_{3} \rightarrow \mathrm{Ca}^{2+}+2 \mathrm{HCO}_{3}^{-}
$$

The mineralogical transformations controlling $\mathrm{pH}$ through reactions 1 to 4 are reported in Fig. 8. The amount of calcite, which is an end-product of reactions $1-4$, increases from 10 to 13.5 $\mathrm{wt} \%$ in the edges.

At Dåva, the best agreement of modeling with the field data was obtained without assuming an additional input of $\mathrm{CO}_{2}$ beside rainwater content. However, the data measured after $6 \mathrm{y}$ in the roadside were finely reproduced by fixing an atmospheric input rate of 50 
$\mathrm{mmol} / \mathrm{dm}^{3} / \mathrm{y}$ approximately. C-S-H and ettringite carbonation is so completed after 6 years, leading to a $\mathrm{pH}$ around 8 in agreement with reaction 5.

$$
\text { [FIGURES 6-7-8] }
$$

\subsection{Release of major elements}

\section{Field data}

At Hérouville, leachate Ca concentrations decrease from $1000 \mathrm{mg} / \mathrm{L}$ to $100 \mathrm{mg} / \mathrm{L}$ during the first year and then remain constant. $\mathrm{SO}_{4}$ concentrations are scattered around a mean value of $150 \mathrm{mg} / \mathrm{L}$ but show a slightly increasing trend on the long term. Al concentrations are low, ranging between 0.1 and $10 \mathrm{mg} / \mathrm{L}$, and become even lower after $10 \mathrm{y}$. Si concentrations are more or less constant, around $5 \mathrm{mg} / \mathrm{L}$. At Dåva, Al concentrations are one order of magnitude higher but eventually drop to a value similar to Hérouville once $\mathrm{pH}$ becomes neutral. The maximum Ca concentrations are also about $100 \mathrm{mg} / \mathrm{L}$ but many values are one order of magnitude smaller. $\mathrm{SO}_{4}$ concentrations are characterized by a decreasing trend during the first year and a convergence to a range of values similar to Hérouville ones. Si concentrations are one order of magnitude lower than the values measured at Hérouville. $\mathrm{CO}_{3}$ concentrations are relatively constant over time, around $10 \mathrm{mg} / \mathrm{L}$.

\section{Modeling}

At Hérouville, the evolution with time of $\mathrm{Ca}$ leachate concentrations is in straight relation with pH-buffering, as shown in Fig. 7. Ca concentration is first controlled by portlandite dissolution, then C-S-H and ettringite dissolutions and, eventually, calcite solubility in equilibrium with atmospheric $\mathrm{CO}_{2}$. The modeling results are in good agreement with the field data though systematically maximized. At Dåva, the modeling overestimates field data. Similar trends are obtained when the C-S-H phases are substituted by pseudo-wollastonite. 
The evolution of $\mathrm{SO}_{4}$ concentration is driven both by hydrodynamics and chemical processes. The early decrease during the first year at both sites is similar to $\mathrm{Cl}$ release. A soluble fraction $\left(\mathrm{CaSO}_{4}\right)$ is evacuated by water discharge and rainwater infiltration. The calculated $\mathrm{SO}_{4}$ concentration is then controlled by ettringite, as long as the $\mathrm{pH}$ remains above 10 , and by secondary gypsum when $\mathrm{pH}$ decreases to 8 . The thermodynamic equilibrium approach produces step-like increase in $\mathrm{SO}_{4}$ concentrations coupled to $\mathrm{pH}$ evolution. Ettringite dissolution yields gypsum and Al-hydroxide precipitation according to reaction 4, as shown in Fig. 8. At Hérouville, XRD analysis indicated ettringite depletion in the ten-year old samples contrarily to the fresh samples (Dabo et al., 2009). According to the $\mathrm{SO}_{4}$ solubility diagrams of Fig. 2, $\mathrm{SO}_{4}$ concentrations should be lower at high $\mathrm{pH}$, in conjunction with ettringite equilibrium, but should increase when $\mathrm{pH}$ decreases during carbonation to reach gypsum saturation. This is roughly the case at Hérouville but not at Dåva.

The evolution with time of Al leachate concentrations is reported in Fig. 6. Constraining $\mathrm{Al}$ concentration by ettringite equilibrium is very sensitive to $\mathrm{pH}$. At Hérouville, the model clearly fails to simulate field data with both ettringite or gibbsite Al control. This was already the case in the modeling of batch tests (Section 4.4). The theoretical very low concentrations calculated with ettringite may, in reality, be out-competed by the numerous secondary mineralogical transformations occurring at field. Moreover, Bodénan et al. (2010) reported important fluctuation of ettringite SI suggesting these phases did not reach equilibrium during leaching experiment applied to bottom ash from MSW fluidized-bed incinerator. At Dåva, the calculated concentrations may represent a lower limit to field data (equivalently with ettringite or gibbsite). When $\mathrm{pH}$ falls below 10, the precipitation of amorphous $\mathrm{Al}(\mathrm{OH})_{3}$ decreases $\mathrm{Al}$ concentrations at both sites.

At Dåva, $\mathrm{CO}_{3}$ solubility control by calcite underestimates by one order of magnitude field data at alkaline $\mathrm{pH}$; the agreement being much better at neutral pH. Dijkstra et al. (2008) 
modified the formation constant $(\log \mathrm{K})$ of calcite according to the generally observed calcite supersaturation in leachate from incineration residues. In the present case, the model nicely reproduces field data in the alkaline range when monohydrocalcite is substituted for calcite (in agreement with the study of Bodénan et al., 2010). $\mathrm{CO}_{3}$ concentrations are better simulated with the calcite solubility control when the $\mathrm{pH}$ drop induced by $\mathrm{CO}_{2}$ "atmospheric" input is taken into account at the Dåva roadside. At Hérouville, the calculated carbonate content of the leachate at neutral $\mathrm{pH}$ are under-estimated by a factor 3 . This small discrepancy is related to the slight overestimation of both $\mathrm{Ca}$ concentration and $\mathrm{pH}$ by the model that induces a decrease of $\mathrm{CO}_{3}$ through the solubility product of calcite.

At the most alkaline $\mathrm{pH}$ values (Hérouville site), the Si solubility control by C-S-H leads to a clear underestimation of field data. Likewise Al, this is induced by the corresponding high $\mathrm{Ca}$ concentrations and the thermodynamic equilibrium approach. Once $\mathrm{pH}$ and $\mathrm{Ca}$ concentration have sufficiently decreased, after $2 \mathrm{y}$, Si concentration become controlled by tobermorite and the model generates data much closer to field. The field data are correctly simulated over a wider $\mathrm{pH}$ range when pseudo-wollastonite is substituted for CS-H phases. At neutral $\mathrm{pH}$, Si concentrations are well reproduced by quartz (or chalcedony) solubility. At Dåva, tobermorite solubility leads to satisfactory results for Si over the full period; quartz becoming a possible controlling phase when $\mathrm{pH}$ drops to 8 .

\subsection{Release of $\mathrm{Ba}, \mathrm{Cu}$ and $\mathrm{Pb}$}

\section{Field data}

Fig. 9 shows the evolution with time of $\mathrm{Ba}, \mathrm{Cu}$ and $\mathrm{Pb}$ concentrations in the leachates at the sampling points (Ba was not measured at Hérouville). At Dåva, Ba leachate concentrations do not vary with time and remain within the range $0.02-0.1 \mathrm{mg} / \mathrm{L}$. The mean concentration in the roadside slopes is slightly smaller than the mean concentration measured below the 
asphalt cover. $\mathrm{Cu}$ leachate concentrations range from 10 to $0.05 \mathrm{mg} / \mathrm{L}$. There is clear decrease of $\mathrm{Cu}$ concentration with time at Hérouville and the Dåva roadsides, which is most probably linked to the release of DOM (Fig. 5). The two sites differ significantly with respect to $\mathrm{Pb}$ leachate concentrations. The Hérouville site is characterized by a fast decrease over the first two years, from 5 to $0.01 \mathrm{mg} / \mathrm{L}$; $\mathrm{Pb}$ leachate concentrations remaining relatively constant on the long term. Most of the $\mathrm{Pb}$ concentrations at Dåva are directly $\leq 0.01 \mathrm{mg} / \mathrm{L}$ without any obvious evolution with time.

\section{Modeling}

The agreement between field and calculated data is particularly good in the case of Ba. The modeling of $\mathrm{Ba}$ concentration is intrinsically linked to the modeling of $\mathrm{SO}_{4}$ concentration through the solubility product of barite. The good agreement demonstrates the global consistency of the present model. However, on the contrary, any degradation of the quality of $\mathrm{SO}_{4}$ modeling content will affect the quality of Ba modeling.

There is a good agreement between field and calculated $\mathrm{Cu}$ concentrations when the $\mathrm{Cu}-\mathrm{DOM}$ interaction is taken into account in the model (Hérouville site only). $\mathrm{Cu}$ release is clearly driven by the combination of transport due to DOM complexation and tenorite equilibrium. It is worth mentioning that tenorite is always in equilibrium, even with respect to the initial leachates in which the apparent solubility is enhanced by DOM complexation. The theoretical curve represents an upper limit for field data, identically to DOC modeling (section 4.3). At Dåva, field data are not far from tenorite solubility on the long term when a substantial fraction of DOM has been leached out.

At Hérouville, the calculated $\mathrm{Pb}$ leachate concentrations are in reasonable agreement with field data. There is also a decrease of 2 orders of magnitude during the first two years, which is linked to $\mathrm{pH}$ evolution in the range $12.5-10$ (at least in the model). While 
carbonation progressively lowers $\mathrm{pH}, \mathrm{Pb}$ solubility is successively controlled in the model by: $\mathrm{Pb}(\mathrm{OH})_{2}(\mathrm{~s})$ in the $\mathrm{pH}$ range $13-11, \mathrm{~Pb}_{2}(\mathrm{OH})_{3} \mathrm{Cl}$ in the range $11-9.5$ and cerussite at $\mathrm{pH}<$ 9. Nevertheless, the model fails to reproduce the low $\mathrm{Pb}$ concentrations, either at neutral $\mathrm{pH}$ at Hérouville or for the full $\mathrm{pH}$ range at Dåva. This was already the case in the modeling of the compliance batch test (Section 4.4). Pb co-precipitation with calcite or sorption on Al-Fehydroxides have been observed in the Hérouville MSWI bottom ash (Dabo et al., 2008).

[FIGURE 9]

\section{Water residence time and temperature effects}

The scattering of leachate data may partly come from variations in water residence time depending on the precipitation regime. Indeed, considering in the model an annual rate of rainwater infiltration combined with a thermodynamic equilibrium is a source of uncertainty with respect to $\mathrm{pH}$ and element concentrations. Some of the precipitation events are more intense and lead to faster leachate transfers inside the road basement (e.g. Dabo et al., 2009). Fast transfers mean low residence times and, therefore, an incomplete dissolution of the solubility-controlling minerals (i.e. thermodynamic equilibrium is not reached). An improved modeling would, therefore, require a kinetic approach for the selected minerals despite their relatively fast kinetics. Field under-saturation may also result from dilution due to the mixing of MSWI BA leachate with rainwater flowing in preferential pathways.

To a lesser extent, seasonal variations of temperature may also produce data scattering. For that purpose, $\mathrm{pH}$ and element concentrations of the Hérouville leachates were calculated at 5, 15 and $30^{\circ} \mathrm{C}$ (Fig. 3 and 6). The differences between the profiles are directly linked to the temperature-dependency of the thermodynamic equilibrium constants in the present modeling approach (i.e. potential catalyzing effects of temperature on microbial 
kinetics are not analyzed here). Temperature effect on $\mathrm{pH}$ is effective for leachates in equilibrium with portlandite, $\mathrm{pH}$ decreases by one unit when temperature rises from 5 to $30^{\circ}$ C. There is no significant temperature effect at slightly alkaline and neutral $\mathrm{pH}$. Temperature effect on the leachate concentrations of major and trace elements is weak in the range $5-30^{\circ}$ $\mathrm{C}$, except for $\mathrm{Pb}$ whose solubility is strongly dependent on $\mathrm{pH}$. $\mathrm{Pb}$ concentration decreases by one order of magnitude from 5 to $30^{\circ} \mathrm{C}$ at strongly alkaline $\mathrm{pH}$; temperature effect is much weaker otherwise.

\section{Conclusions}

The comparison of leachate chemistry at the Hérouvile and Dåva pilot-scale roads helps to shed light on common processes, but also discrepancies, in view of rationalizing the leachate long-term evolution. Calculated saturation indices and solubility diagrams have been combined to batch test modeling to set a simplified geochemical model of the two bottom ash materials. A common reactive transport model has then been applied to both pilot-scale roads. At Hérouville, $\mathrm{pH}$ and the concentration of most major and trace elements quickly drop during the first two years to asymptotically reach a set of minimum values over 10 years. The decrease is less pronounced at Dåva. The evolution of $\mathrm{pH}$ and major element concentrations are fairly well related to the following $\mathrm{pH}$-buffering sequence: portlandite (Hérouville only), C-S-H or pseudo-wollastonite and, finally, calcite in equilibrium with atmospheric $\mathrm{CO}_{2} \cdot \mathrm{Al}(\mathrm{OH})_{3}$, barite, ettringite, monohydrocalcite may also control leachate chemistry. $\mathrm{Cu}$ release is correctly modeled by DOM complexation and tenorite equilibrium. At Hérouville, $\mathrm{Pb}$ concentration decreases by two orders of magnitude in the $\mathrm{pH}$ range $12.5-$ 10. The solubility-controlled approach fails to reproduce the lowest $\mathrm{Pb}$ concentrations, requiring sorption or co-precipitation modeling. Temperature has no significant effect on the modeling of the leachate chemistry in the range $5-30{ }^{\circ} \mathrm{C}$, except at high $\mathrm{pH}$. Effects at road 
edges and roadside slopes have been show to be important for the release of the less reactive elements and, possibly, for carbonation processes driven by atmospheric $\mathrm{CO}_{2}$ inputs.

The relevancy of the C-S-H/pseudo-wollastonite to simulate the $\mathrm{pH}$ transient stage in the range $12-10.5$ should be further investigated experimentally. The reactive transport model may be an useful tool for environmental impact assessments, but this requires to take into account other potential contaminants. Further developments of HYTEC is needed for implementing existing gas transport models to better assess carbonation at field scale.

\section{Acknowledgements}

The authors thank Ivan Drouadaine from EUROVIA (France) for supporting leachate sampling and analyses at the Hérouville site. Three anonymous reviewers are also gratefully acknowledged for their detailed comments and fruitful suggestions. 


\section{References}

Åberg, A., Kumpiene, J., Ecke, H., 2006. Evaluation and prediction of emissions from a road built with bottom ash from municipal solid waste incineration (MSWI), Sc. Total Environ. 355, 1-12.

Allison, J.D., Brown, D.S. Novo-Gradac, K. J., 1990. MINTEQA2/PRODEF2, A Geochemical Assessment Model for Environmental Systems: Version 3.0 User's Manual, U.S. Environ. Prot. Agency, Athens (USA).

Apul, D.S., Gardner, K.H., Eighmy, T.T., 2007. Modeling hydrology and reactive transport in roads : The effect of cracks, the edge, and contaminant properties, Waste Manage. 27, $1465-1475$.

Astrup, T., Joris J. Dijkstra, J.J., Comans, R.N.J., van der Sloot, H.A., Christensen, T.H., 2006. Geochemical modeling of leaching from MSWI air-pollution-control residues, Environ. Sci. Technol. 40, 3551-3557.

Baranger, P., Azaroual, M., Freyssinet, P., Lanini, S., Piantone, P., 2002. Weathering of a MSW bottom ash heap: a modelling approach, Waste Manage. 22, 173-179.

Blanc, Ph., Bourbon, X., Lassin, A., Gaucher, E.C., 2010. Chemical model for cement-based materials: Temperature dependence of thermodynamic functions for nanocrystalline and crystalline C-S-H phases, Cement Concrete Res. 40, 851-866.

Bodénan, F., Guyonnet, D., Piantone, Blanc, P., 2010. Mineralogy and pore water chemistry of a boiler ash from a MSW fluidized-bed incinerator, Waste Manage. 30, 1280-1289.

Bothe, J., Brown, P., 2004. PhreeqC modeling of Friedel's salt equilibria at 23C. Cement Concret Res. 34, 1057-1063.

Dabo, D., Raimbault, L., Badreddine, R., Chaurand, P., Rose, J., De Windt, L., 2008. Characterisation of Glassy and Heterogeneous Cementing Phases of Municipal Solid 
Waste of Incineration (MSWI) Bottom Ash, Australasian Institute of Mining and Metallurgy Publication Series, pp. 95-99.

Dabo, D., Badreddine, R., De Windt, L., Drouadaine , I., 2009. Ten-year chemical evolution of leachate and municipal solid waste incineration bottom ash used in a test road site, J. Hazard. Mater. 172, 904-913.

Damidot, D., Glasser, F.P., 1993. Thermodynamic investigation of the $\mathrm{CaO}-\mathrm{Al}_{2} \mathrm{O}_{3}-\mathrm{CaSO}_{4}-$ $\mathrm{H}_{2} \mathrm{O}$ system at $25^{\circ} \mathrm{C}$ and the influence of $\mathrm{Na}_{2} \mathrm{O}$, Cement Concrete Res. 23, 221-238.

De Windt, L., Badreddine, R., 2007. Modelling of long-term dynamic leaching tests applied to solidified/stabilised waste, Waste Manage. 27, 1638-1647.

Dijkstra, J.J., Meeussen, J.C.L., Van der Sloot, H.A., Comans, R.N.J., 2008. A consistent geochemical modelling approach for the leaching and reactive transport of major and trace elements in MSWI bottom ash, Appl. Geochem. 23, 1544-1562.

Flyhammar, P., Bendz, D., 2006. Leaching of different elements from subbase layers of alternative aggregates in pavement constructions, J. Hazard. Mater. 137, 603-611.

Golubev, S.V., Pokrovsky, O.S., Schott, J., 2006. Experimental determination of the effect of dissolved $\mathrm{CO} 2$ on the dissolution kinetics of $\mathrm{Mg}$ and $\mathrm{Ca}$ silicates at $25^{\circ} \mathrm{C}$. Chem. Geol. $217,227-238$.

Guymon G.L., 1994. Unsaturated zone hydrology, Prentice Hall Ed., Englewood Cliffs (USA).

Guyonnet, D., Bodénan, F., Brons-Laot, G., Burnol, A., Chateau, L., Crest, M., Méhu, J., Moszkowicz, P., Piantone, P., 2008. Multiple-scale dynamic leaching of a municipal solid waste incineration ash, Waste Manage. 28, 1963-1976.

Hjelmar, O., Holm, J., Crillesen, K., 2007. Utilisation of MSWI bottom ash as subbase in road construction : First results from a large-scale test site, J. Hazard. Mater. 139, 471-480. 
Hyks, J., Astrup, T., Christensen, T.H., 2009. Leaching from MSWI bottom ash: Evaluation of non-equilibrium in column percolation experiments, Waste Manage. 29, 522-529.

Jeong, S.M., Osako, M., Kim, Y.J., 2005. Utilizing a database to interpret leaching characteristics of lead from bottom ash of municipal solid waste of incinerators, Waste Manage. 25, 694-701.

Johnson, C.A., Kaeppeli, M., Brandenberger, S., Ulrich, A., Baumann, W. 1999. Hydrological and geochemical factors affecting leachate composition in municipal solid waste incinerator bottom ash: Part II. The geochemistry of leachate from Landfill Lostorf, Switzerland, J. Contam. Hydrol. 40, 239-259.

Kosson, D.S. , van der Sloot, H.A., Eighmy, T.T, 1996. An approach for estimation of contaminant release during utilization and disposal of municipal waste combustion residues, J. Hazard. Mat. 47, 43-75.

Lidelöw, S., Lagerkvist, A., 2007. Evaluation of leachate emissions from crushed rock and municipal solid waste incineration bottom ash used in road construction, Waste Manage. 27, 1356-1365.

Meima, J.A., Comans, R.N.J., 1997. Geochemical modeling of weathering reactions in municipal solid waste incinerator bottom ash, Environ. Sci. Technol. 31, 1269-1276.

Mostbauer P., Lechner P., 2006. Weathering of MSWI bottom ash in laboratory test cells and under field conditions - Effect on metal and metalloid mobility. WASCON 2006 conference proceedings, Belgrade (Serbia).

Park, J.Y., Batchelor, B., 2002. A multi-component numerical leach model coupled with a general chemical speciation code, Water Res. 36, 156-166.

Perkins, R., Palmer, C., 1999. Solubility of ettringite $\left(\mathrm{Ca}_{6}\left[\mathrm{Al}(\mathrm{OH})_{6}\right]_{2}\left(\mathrm{SO}_{4}\right)_{3} \cdot 26 \mathrm{H}_{2} \mathrm{O}\right)$ at 5$75^{\circ}$ C. Geochim. Cosmochim. Ac. 63, 1969-1980. 
Piantone, P., Bodénan, F., Chatelet-Snidaro, L., 2004. Mineralogical study of secondary mineral phases from weathered MSWI bottom ash: implications for the modelling and trapping of heavy metals, Appl. Geochem. 19, 1891-1904.

Rendek, E., Ducom, G., Germain, P. (2006). Influence of organic matter on municipal solid waste incinerator bottom ash carbonation, Chemosphere 64, 1212-1218.

Schmidt, T., Lothenbach, B., Romer, M., Scrivener, K., Rentsch, D., Figi, R., 2008. A thermodynamic and experimental study of the conditions of thaumasite formation, Cement Concrete Res. 38, 337-349.

Speiser, C., Baumann, T., Niessner, R., 2000. Morphological and chemical characterization of calcium-hydrate phases formed in alteration processes of deposited municipal solid waste incinerator bottom ash, Environ. Sci. Technol. 34, 5030-5037.

Stronach, S.A., Glasser, F.P., 1997. Modeling the impact of abundant geochemical components on phase stability and solubility of the $\mathrm{CaO}-\mathrm{SiO}_{2}-\mathrm{H}_{2} \mathrm{O}$ systems at $25^{\circ} \mathrm{C}: \mathrm{Na}^{+}$, $\mathrm{K}^{+}, \mathrm{SO}_{4}{ }^{2-}, \mathrm{Cl}^{-}$and $\mathrm{CO}_{3}{ }^{2-}$. Adv. Cem. Res. 9, 167-181.

Suer, P., Lindqvist, J.E., Arm, M., Frogner-Kockum, P., 2009. Reproducing ten years of road ageing - Accelerated carbonation and leaching of EAF steel slag, Sc. Total Environ. $407,5110-5118$.

van der Lee, J., De Windt, L., Lagneau, Goblet, P., 2003. Module-oriented modeling of reactive transport with HYTEC. Comput. Geosci. 29, 265-275.

van Zoemeren, A., Comans, R. N. J., 2004. Contribution of natural organic matter to copper leaching from municipal solid waste incinerator bottom ash, Environ. Sc. Technol. 38, $3927-3932$.

Wolery, T., 1992. EQ3/6. A software package for geochemical modelling of aqueous systems: package overview and installation guide (version 7.0). Technical Report UCRL-MA110662 PT I ed., Lawrence Livermore National Laboratory, USA. 
Table 1. Thermodynamic equilibrium constants of the solid phases considered in the calculation of saturation indices and the reactive transport modeling.

\begin{tabular}{|c|c|c|c|c|}
\hline Mineral & Reaction of formation & $\operatorname{LogK} 0{ }^{\circ} \mathrm{C}$ & $25^{\circ} \mathrm{C}$ & Ref. \\
\hline Amorphous $\mathrm{Al}(\mathrm{OH})_{3}$ & $\mathrm{Al}^{3+}+3 \mathrm{H}_{2} \mathrm{O} \rightarrow \mathrm{Al}(\mathrm{OH})_{3}(\mathrm{am})+3 \mathrm{H}^{+}$ & -12.2 & -10.4 & [a] \\
\hline Calcite & $\mathrm{Ca}^{2+}+\mathrm{CO}_{3}{ }^{2-} \rightarrow \mathrm{CaCO}_{3}$ & 8.4 & 8.5 & [a] \\
\hline C-S-H 0.8 & $0.8 \mathrm{Ca}^{2+}+\mathrm{H}_{4} \mathrm{SiO}_{4}-0.4 \mathrm{H}_{2} \mathrm{O} \rightarrow \mathrm{C}-\mathrm{S}-\mathrm{H} 0.8+1.6 \mathrm{H}^{+}$ & - & -11.1 & [b] \\
\hline C-S-H 1.1 & $1.1 \mathrm{Ca}^{2+}+\mathrm{H}_{4} \mathrm{SiO}_{4}+0.2 \mathrm{H}_{2} \mathrm{O} \rightarrow$ C-S-H $1.1+2.2 \mathrm{H}^{+}$ & - & -16.7 & [b] \\
\hline C-S-H 1.8 & $1.8 \mathrm{Ca}^{2+}+\mathrm{H}_{4} \mathrm{SiO}_{4}+1.6 \mathrm{H}_{2} \mathrm{O} \rightarrow \mathrm{C}-\mathrm{S}-\mathrm{H} 1.8+3.6 \mathrm{H}^{+}$ & - & -32.6 & [b] \\
\hline Ettringite & $2 \mathrm{Al}^{3+}+6 \mathrm{Ca}^{2+}+3 \mathrm{SO}_{4}{ }^{2-}+38 \mathrm{H}_{2} \mathrm{O} \rightarrow \mathrm{Ca}_{6} \mathrm{Al}_{2}\left(\mathrm{SO}_{4}\right)_{3}(\mathrm{OH})_{12}: 26 \mathrm{H}_{2} \mathrm{O}+12 \mathrm{H}^{+}$ & -63.3 & -56.9 & {$[\mathrm{c}, \mathrm{d}]$} \\
\hline Foshagite & $4 \mathrm{Ca}^{2+}+3 \mathrm{H}_{4} \mathrm{SiO}_{4}-\mathrm{H}_{2} \mathrm{O} \rightarrow \mathrm{Ca}_{4} \mathrm{Si}_{3} \mathrm{O}_{9}(\mathrm{OH})_{2}+8 \mathrm{H}^{+}$ & -71.4 & -65.9 & [d] \\
\hline Friedel's salt & $4 \mathrm{Ca}^{2+}+2 \mathrm{Al}^{3+}+2 \mathrm{Cl}^{-}+12 \mathrm{H}_{2} \mathrm{O} \rightarrow \mathrm{Ca}_{4} \mathrm{Al}_{2} \mathrm{Cl}_{2}(\mathrm{OH})_{12}: 4 \mathrm{H}_{2} \mathrm{O}+12 \mathrm{H}^{+}$ & -73 & -63.8 & [e] \\
\hline Gehlenite & $2 \mathrm{Ca}^{2+}+2 \mathrm{Al}^{3+}+\mathrm{H}_{4} \mathrm{SiO}_{4}+3 \mathrm{H}_{2} \mathrm{O} \rightarrow \mathrm{Ca}_{2} \mathrm{Al}_{2} \mathrm{SiO}_{7}+10 \mathrm{H}^{+}$ & -64.6 & -56.8 & [a] \\
\hline Gibbsite & $\mathrm{Al}^{3+}+3 \mathrm{H}_{2} \mathrm{O} \rightarrow \mathrm{Al}(\mathrm{OH})_{3}+3 \mathrm{H}^{+}$ & -10.3 & -8.8 & [a] \\
\hline Gypsum & $\mathrm{Ca}^{2+}+\mathrm{SO}_{4}{ }^{2-}+2 \mathrm{H}_{2} \mathrm{O} \rightarrow \mathrm{CaSO}_{4}: 2 \mathrm{H}_{2} \mathrm{O}$ & 4.9 & 4.8 & [a] \\
\hline Halite & $\mathrm{Na}^{+}+\mathrm{Cl}^{-} \rightarrow \mathrm{NaCl}$ & -1.5 & -1.6 & [a] \\
\hline Hillebrandite & $2 \mathrm{Ca}^{2+}+\mathrm{H}_{4} \mathrm{SiO}_{4}+\mathrm{H}_{2} \mathrm{O} \rightarrow \mathrm{Ca}_{2}(\mathrm{OH})_{2} \mathrm{SiO}_{3}+4 \mathrm{H}^{+}$ & -40.0 & -36.8 & [d] \\
\hline Monosulfoaluminate & $2 \mathrm{Al}^{3+}+4 \mathrm{Ca}^{2+}+\mathrm{SO}_{4}^{2-}+12 \mathrm{H}_{2} \mathrm{O} \rightarrow \mathrm{Ca}_{4} \mathrm{Al}_{2} \mathrm{SO}_{4}(\mathrm{OH})_{12}+12 \mathrm{H}^{+}$ & - & -73.0 & [f] \\
\hline Monohydrocalcite & $\mathrm{Ca}^{2+}+\mathrm{CO}_{3}^{2-}+\mathrm{H}_{2} \mathrm{O} \rightarrow \mathrm{CaCO}_{3}: \mathrm{H}_{2} \mathrm{O}$ & 7.6 & 7.7 & [d] \\
\hline Pseudo-wollastonite & $\mathrm{Ca}^{2+}+\mathrm{H}_{4} \mathrm{SiO}_{4}-\mathrm{H}_{2} \mathrm{O} \rightarrow \mathrm{CaSiO}_{3}+2 \mathrm{H}^{+}$ & -15.3 & -13.9 & [a] \\
\hline Portlandite & $\mathrm{Ca}^{2+}+2 \mathrm{H}_{2} \mathrm{O} \rightarrow \mathrm{Ca}(\mathrm{OH})_{2}+2 \mathrm{H}^{+}$ & -24.7 & -22.7 & [a] \\
\hline Quartz & $\mathrm{H}_{4} \mathrm{SiO}_{4} \rightarrow \mathrm{SiO}_{2}+2 \mathrm{H}_{2} \mathrm{O}$ & 4.4 & 4.0 & [a] \\
\hline Sylvite & $\mathrm{K}^{+}+\mathrm{Cl}^{-} \rightarrow \mathrm{KCl}$ & -0.5 & -0.9 & [d] \\
\hline Thaumasite & $\begin{array}{l}6 \mathrm{Ca}^{2+}+2 \mathrm{H}_{4} \mathrm{SiO}_{4}+2 \mathrm{CO}_{3}{ }^{2-}+2 \mathrm{SO}_{4}{ }^{2-}+28 \mathrm{H}_{2} \mathrm{O} \rightarrow \\
\mathrm{Ca}_{6}\left(\mathrm{SiO}_{3}\right)_{2} \mathrm{O}_{16}\left(\mathrm{CO}_{3}\right)_{2}\left(\mathrm{SO}_{4}\right)_{2}: 30 \mathrm{H}_{2} \mathrm{O}+4 \mathrm{H}^{+}\end{array}$ & -67.0 & -63.8 & [g] \\
\hline Tobermorite & $5 \mathrm{Ca}^{2+}+6 \mathrm{H}_{4} \mathrm{SiO}_{4}-2 \mathrm{H}_{2} \mathrm{O} \rightarrow \mathrm{Ca}_{5} \mathrm{Si}_{6} \mathrm{O}_{16}(\mathrm{OH})_{2}: 4 \mathrm{H}_{2} 0+10 \mathrm{H}^{+}$ & -67.0 & -63.8 & [d] \\
\hline Anglesite & $\mathrm{Pb}^{2+}+\mathrm{SO}_{4}^{2-} \rightarrow \mathrm{PbSO}_{4}$ & 7.9 & 7.8 & [a] \\
\hline Barite & $\mathrm{Ba}^{2+}+\mathrm{SO}_{4}^{2-} \rightarrow \mathrm{BaSO}_{4}$ & 10.4 & 10.0 & [a] \\
\hline Cerussite & $\mathrm{Pb}^{2+}+\mathrm{CO}_{3}{ }^{2-} \rightarrow \mathrm{PbCO}_{3}$ & 13.5 & 13.1 & [a] \\
\hline $\mathrm{Cu}(\mathrm{OH})_{2}$ & $\mathrm{Cu}^{2+}+2 \mathrm{H}_{2} \mathrm{O} \rightarrow \mathrm{Cu}(\mathrm{OH})_{2}+2 \mathrm{H}^{+}$ & -9.7 & -8.6 & [a] \\
\hline Hydrocerussite & $3 \mathrm{~Pb}^{2+}+2 \mathrm{CO}_{3}{ }^{2-}+2 \mathrm{H}_{2} \mathrm{O} \rightarrow \mathrm{Pb}_{3}\left(\mathrm{CO}_{3}\right)_{2}(\mathrm{OH})_{2}+2 \mathrm{H}^{+}$ & - & 17.5 & [a] \\
\hline Malachite & $2 \mathrm{Cu}^{2+}+\mathrm{CO}_{3}{ }^{2-}+2 \mathrm{H}_{2} \mathrm{O} \rightarrow \mathrm{Cu}_{2} \mathrm{CO}_{3}(\mathrm{OH})_{2}+2 \mathrm{H}^{+}$ & 4.1 & 5.2 & [a] \\
\hline $\mathrm{Pb}(\mathrm{OH})_{2}$ & $\mathrm{~Pb}^{2+}+2 \mathrm{H}_{2} \mathrm{O} \rightarrow \mathrm{Pb}(\mathrm{OH})_{2}+2 \mathrm{H}^{+}$ & - & -11.0 & [h] \\
\hline $\mathrm{Pb}_{2}(\mathrm{OH})_{3} \mathrm{Cl}$ & $2 \mathrm{~Pb}^{2+}+\mathrm{Cl}^{-}+3 \mathrm{H}_{2} \mathrm{O} \rightarrow \mathrm{Pb}_{2}(\mathrm{OH})_{3} \mathrm{Cl}+3 \mathrm{H}^{+}$ & - & -8.8 & [a] \\
\hline Tenorite & $\mathrm{Cu}^{2+}+\mathrm{H}_{2} \mathrm{O} \rightarrow \mathrm{CuO}+2 \mathrm{H}^{+}$ & -8.7 & -7.6 & [a] \\
\hline Witherite & $\mathrm{Ba}^{2+}+\mathrm{CO}_{3}^{2-} \rightarrow \mathrm{BaCO}_{3}$ & 8.6 & 8.6 & [a] \\
\hline
\end{tabular}

[a] MINTEQ, Allison et al. (1991), [b] fit from Stronach and Glasser (1997), [c] Perkins and Palmer (1999), [d] EQ3/6, Wolery (1992),

[e] Bothe and Brown (2004), [f] Damidot and Glasser (1993),[g] Schmidt et al. (2008), [h]Adjusted, see De Windt and Badreddine(2007). 
Table 2.

Transport parameters used in the reactive transport calculations.

\begin{tabular}{rrrr}
\hline & $\begin{array}{r}\text { Hydraulic } \\
\text { conductivity } \\
\mathrm{K}[\mathrm{m} / \mathrm{s}]\end{array}$ & $\begin{array}{r}\text { Pore diffusion } \\
\text { coefficient } \\
\mathrm{D}_{\mathrm{p}}\left[\mathrm{m}^{2} / \mathrm{s}\right]\end{array}$ & $\begin{array}{r}\text { Effective } \\
\text { porosity } \\
\omega[\%]\end{array}$ \\
\hline Hérouville & & & - \\
Asphalt cover & $2 \times 10^{-7}$ & $10^{-10}$ & 30 \\
BA subbase & $5 \times 10^{-6}$ & $10^{-9}$ & 30 \\
BA pathway & $10^{-3}$ & & \\
(geomembrane) & & & - \\
Dåva & & & \\
Asphalt cover & $5 \times 10^{-6}$ & $10^{-9}$ & 30 \\
Gravel and sand & $10^{-5}$ & $10^{-9}$ & 30 \\
BA subbase & $5 \times 10^{-6}$ & &
\end{tabular}


Table 3.

Calculated saturation indices (SI) for a selection of leachates representative of successive weathering stages (the solid phases considered in the reactive transport modeling are in bold).

\begin{tabular}{|c|c|c|c|c|c|c|c|c|c|}
\hline & $\begin{array}{r}\text { Hérou- } \\
\text { ville }\end{array}$ & & & & $\begin{array}{r}\text { Dåva } \\
\text { (slope) }\end{array}$ & & & & $\begin{array}{r}\text { Dåva } \\
\text { (pav.) }\end{array}$ \\
\hline Time & $+7 \mathrm{~d}$ & $+250 \mathrm{~d}$ & $+3 y$ & $+10 y$ & $+13 \mathrm{~d}$ & $+250 \mathrm{~d}$ & $+3 y$ & $+6 y$ & $+3 y$ \\
\hline Temp. $\left[{ }^{\circ} \mathrm{C}\right]$ & 22 & 18 & 17 & 19 & 12 & 24 & 12 & 15 & 8 \\
\hline $\begin{array}{l}\text { Cement-type } \\
\text { phases }\end{array}$ & 12.4 & 11.4 & 8.3 & 7.6 & 11.1 & 10.7 & 11.1 & 7.8 & 10.8 \\
\hline C-S-H 0.8 & -0.6 & -0.3 & -4.0 & -5.1 & - & - & - & -5.7 & - \\
\hline C-S-H 1.1 & 0.8 & 0.2 & -5.5 & -7.0 & - & - & - & -7.5 & - \\
\hline C-S-H 1.8 & 0.8 & -1.5 & -11.9 & -14.2 & - & - & - & -14.5 & - \\
\hline Tobermorite & $\begin{array}{r}4.7 \\
(0.8)\end{array}$ & $\begin{array}{r}4.2 \\
(0.7)\end{array}$ & $\begin{array}{r}-4.0 \\
(-0.7)\end{array}$ & $\begin{array}{l}-26.7 \\
(-4.5)\end{array}$ & - & - & - & $\begin{array}{l}-30 \\
(-5)\end{array}$ & - \\
\hline Foshagite & 1.6 & -2.5 & -25 & -29.5 & - & - & - & -31.5 & - \\
\hline (1) & $(0.5)$ & $(-0.8)$ & $(-8.3)$ & $(-9.8)$ & & & & $(-10.5)$ & \\
\hline Hillebrandite & 0.6 & -2.5 & -14.4 & -16.6 & - & - & - & 17.3 & - \\
\hline Thaumasite & 3.1 & -7.4 & -21.4 & -9.2 & - & - & - & -13.8 & - \\
\hline Ettringite & 6.3 & 0.1 & -14.5 & -16.7 & 1.5 & -2.6 & -0.1 & -18.6 & -2.8 \\
\hline Monosulfoal. & 1.4 & -4.8 & -19.4 & -22.6 & -4.7 & -6.1 & -5.3 & -23.4 & -8.4 \\
\hline Friedel's salt & 2.3 & -2.6 & -17.5 & -23.5 & 2.1 & -5.4 & -3.1 & -21.1 & -1.9 \\
\hline Portlandite & -0.3 & -2.9 & -9.7 & -10.5 & -4.3 & -4.8 & -4.4 & -10.7 & -5.9 \\
\hline $\begin{array}{l}\text { Other phases } \\
\text { (major } \\
\text { elements) }\end{array}$ & & & & & & & & & \\
\hline $\mathrm{Al}(\mathrm{OH})_{3}(\mathbf{a m})$ & -3.9 & -3.0 & 0.0 & -0.5 & -1.0 & 0.6 & -0.8 & -0.4 & -0.1 \\
\hline Calcite & - & - & - & 0.1 & 1.0 & - & 1.2 & -0.9 & 0.8 \\
\hline Monohydrocalc. & - & - & - & -0.7 & 0.2 & - & 0.4 & -1.7 & 0.0 \\
\hline Gehlenite & -6.4 & -7.7 & -14 & -17.2 & - & - & 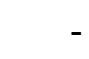 & -17.7 & - \\
\hline Gibbsite & -2.2 & -1.3 & 1.7 & 1.1 & 0.8 & 0.9 & 0.9 & 1.3 & 1.7 \\
\hline Gypsum & -0.9 & -1.1 & -1.3 & -0.6 & -0.9 & -1.5 & -1.4 & -1.5 & -1.5 \\
\hline P-Wollastonite & 1.2 & 0.7 & -4.5 & -5.7 & - & - & - & -6.4 & - \\
\hline Quartz & -3.3 & -1.3 & 0.4 & 0.1 & - & - & - & -0.6 & - \\
\hline $\begin{array}{l}\text { Other phases } \\
\text { (trace elements) }\end{array}$ & & & & & & & & & \\
\hline Barite & - & - & - & - & 0.4 & -0.1 & 0.4 & 0.4 & 0.6 \\
\hline Witherite & 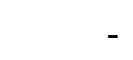 & - & - & - & -2.9 & - & -2.2 & -4.1 & -2.3 \\
\hline Anglesite & -9.7 & -7.8 & -3.2 & -4.6 & -8.4 & -7.4 & -8.4 & -5.5 & -7.3 \\
\hline Cerussite & - & - & - & -2.1 & -4.8 & - & -3.9 & -3.2 & -3.1 \\
\hline Hydrocerussite & - & - & - & -7.7 & -9.8 & - & -7.7 & -9.8 & -6.1 \\
\hline Litharge & -1.9 & -2.3 & -4.3 & -7.5 & -4.4 & -3.5 & -4.0 & -7.5 & -4.1 \\
\hline $\mathrm{Pb}(\mathrm{OH})_{2}(\mathrm{~s})$ & -0.1 & 0.2 & -2.1 & -5.4 & -2.1 & -1.7 & -1.7 & -5.3 & -1.5 \\
\hline $\mathrm{Pb}_{2}(\mathrm{OH})_{3} \mathrm{Cl}$ & -1.1 & -0.8 & -1.7 & -8.2 & -2.7 & -2.4 & -4.4 & -7.8 & -2.3 \\
\hline $\mathrm{Cu}(\mathrm{OH})_{2}{ }^{(2)}$ & 1.0 & 0.4 & -0.5 & -0.8 & 0.1 & 0.0 & -0.9 & -1.8 & 0.0 \\
\hline Malachite $^{(2)}$ & - & - & - & 0.4 & -3.9 & - & -5.2 & -2.7 & -2.7 \\
\hline Tenorite $^{(2)}$ & 2.1 & 1.6 & 0.5 & 0.2 & 1.0 & 1.0 & 0.2 & -0.7 & 1.0 \\
\hline
\end{tabular}

(1) Normalized to 1 atom of Si for comparison with the other C-S-H phases. (2) The interaction between $\mathrm{Cu}$ and the dissolved organic matter is not taken into account for the SI calculations. 
Table 4.

Initial mineralogical content of the MSWI BA considered for the batch and reactive transport modeling.

\begin{tabular}{|c|c|c|c|c|c|}
\hline & $\begin{array}{r}\text { Hérouville } \\
{\left[\text { wt. } \%{ }^{(1)}\right]}\end{array}$ & $\begin{array}{r}\text { Dåva } \\
\text { [wt.\%] }\end{array}$ & & $\begin{array}{r}\text { Hérouville } \\
{[\mathrm{wt} . \%]}\end{array}$ & $\begin{array}{r}\text { Dåva } \\
\text { [wt.\%] }\end{array}$ \\
\hline Calcite & 10 & 10 & Halite & 0.28 & 0.35 \\
\hline $\begin{array}{l}\text { Hillebrandite or P- } \\
\text { wollastonite }\end{array}$ & 2.5 & - & Portlandite & 1 & - \\
\hline $\begin{array}{l}\text { Tobermorite or P- } \\
\text { wollastonite }\end{array}$ & - & 2.5 & Sylvite & 0.08 & 0.05 \\
\hline Ettringite & 1 & 1 & Litharge & 0.1 & 0.1 \\
\hline Gypsum & 0.05 & 0.05 & Tenorite & 0.1 & 0.1 \\
\hline
\end{tabular}

(1) $\mathrm{wt} \%$ of dried MSWI BA. 


\section{Figure captions}

Fig. 1 Schematic representation of the two pilot-scale roads and modeling grids with the sampling collectors marked by the symbol $\otimes$. Due to symmetry, half a cross section is sufficient for the Dåva grid. The black upper boundary condition of rainwater infiltration and the grid nodes in white are used to simulate the partial runoff of rainwater at the surface.

Fig. 2. Plot of the leachate experimental data on $\mathrm{SO}_{4}$ and $\mathrm{Al}$ solubility diagrams calculated at $25{ }^{\circ} \mathrm{C}$ for conditions representative of the leachate (Hérouville: tot. $\mathrm{Al}^{3+}=3 \times 10^{-5}$, tot. $\mathrm{Ca}^{2+}=2.5 \times 10^{-3}$, tot. $\mathrm{SO}_{4}{ }^{2-}$ $=1 \times 10^{-3}$; Dåva: tot. $\mathrm{Al}^{3+}=1 \times 10^{-4}$, tot. $\mathrm{Ca}^{2+}=1 \times 10^{-3}$, tot. $\mathrm{SO}_{4}{ }^{2-}=1 \times 10^{-3}$ ). In the Dåva case the symbols $\bigcirc$ and - stand for leachate collector under the slope and the road, respectively.

Fig. 3. Experimental and modeling data of batch tests applied to the Hérouville and Dåva MSWI bottom ashes.

Fig. 4. Calculated average annual Darcy flow and $\mathrm{Cl}$ concentration profiles after 3 years of leaching. The upper vectors correspond to water runoff at the surface of the asphalt towards the soil (Hérouville) or the ditch (Dåva).

Fig. 5. Evolution with time of the leachante concentrations of elements and dissolved organic carbon at the sampling points. The saturation indices of the leachates surrounded by the square symbols are reported in Table 3.

Fig. 6. Evolution with time of leachate $\mathrm{pH}$ at the sampling points assessing temperature effect and $\mathrm{CO}_{2}$ inputs. The saturation indices of the leachates surrounded by the square symbol are reported in Table 3.

Fig. 7. Evolution with time of major element concentrations in the leachates at the sampling points assessing temperature effect, $\mathrm{CO}_{2}$ inputs and mineralogical variants of the model. The saturation indices of the leachates surrounded by the square symbol are reported in Table 3.

Fig. 8. Calculated mineralogical evolution of the MSWI bottom ashes close to the sampling point at Hérouville. Left: evolution with time of the pH-buffering minerals. Right: transformation of ettringite into calcite, gypsum and aluminum hydroxide. 
Fig. 9. Evolution with time of $\mathrm{Ba}, \mathrm{Cu}$ and $\mathrm{Pb}$ concentrations in the leachates at the sampling points assessing temperature effect and $\mathrm{Cu}$ complexation by dissolved organic matter. The saturation indices of the leachates surrounded by the square symbol are reported in Table 3. 
Hérouville

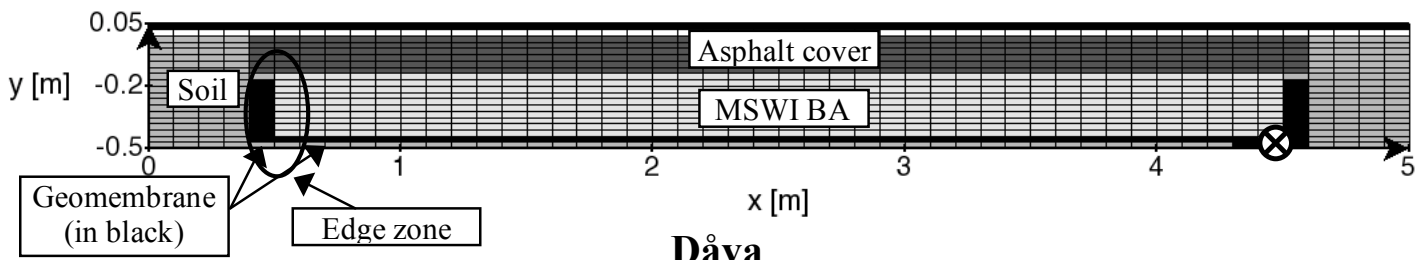

Dåva

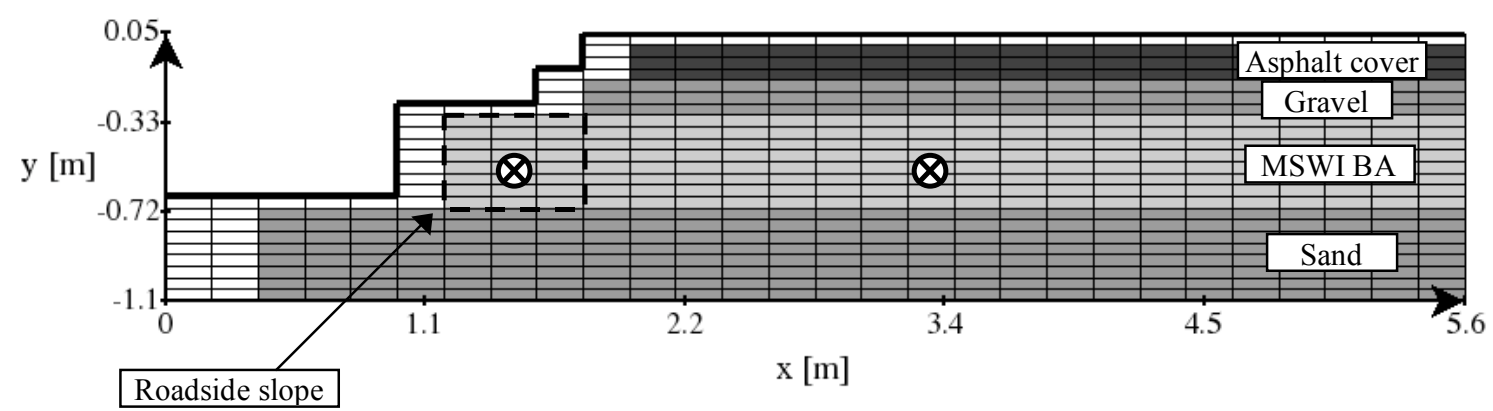

Figure 1 

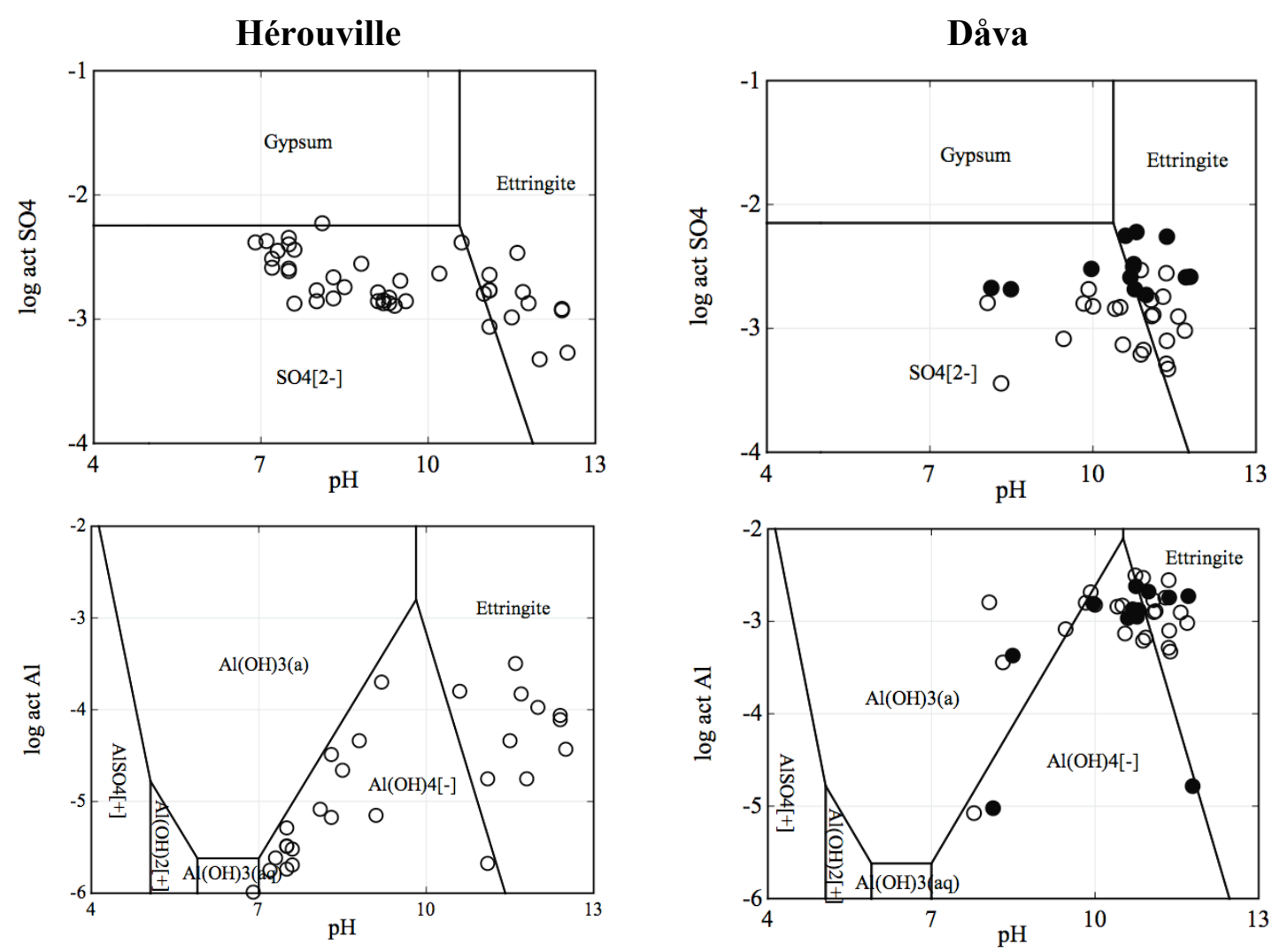

Figure 2 
(a) Batch tests of increasing L/S (Hérouville)

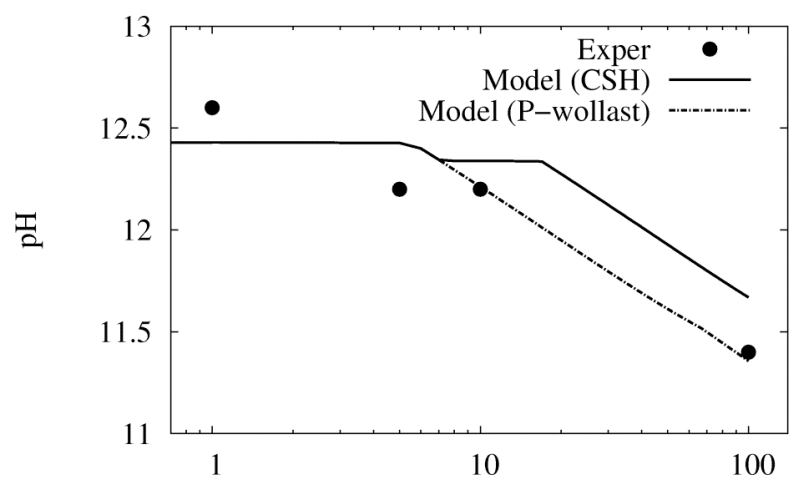

(c) Batch test at $\mathrm{L} / \mathrm{S}=10$ (Hérouville)

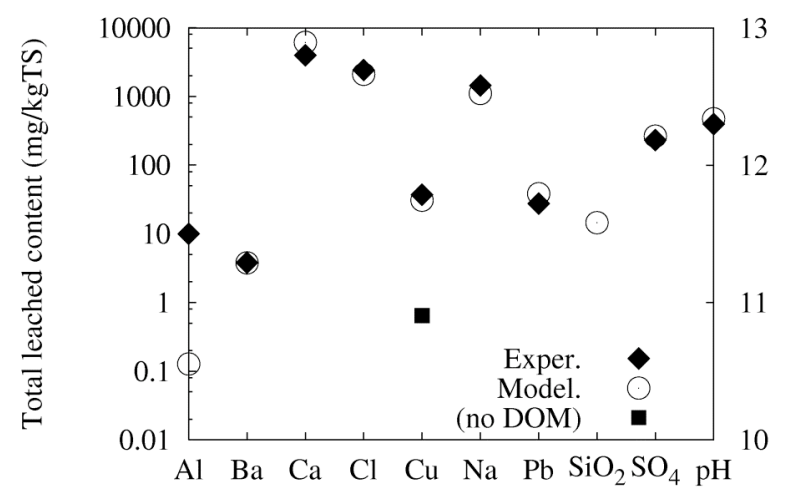

(b) Batch tests of increasing $\mathrm{L} / \mathrm{S}$ (Hérouville)

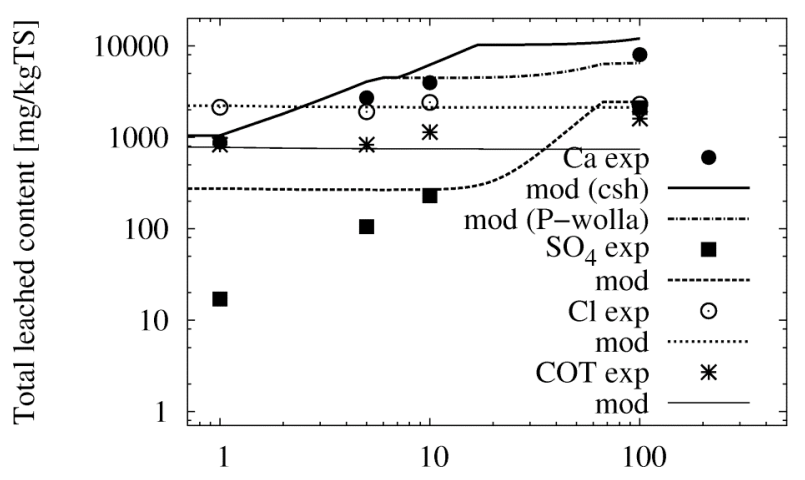

(d) Batch test at $\mathrm{L} / \mathrm{S}=10$ (Dåva)

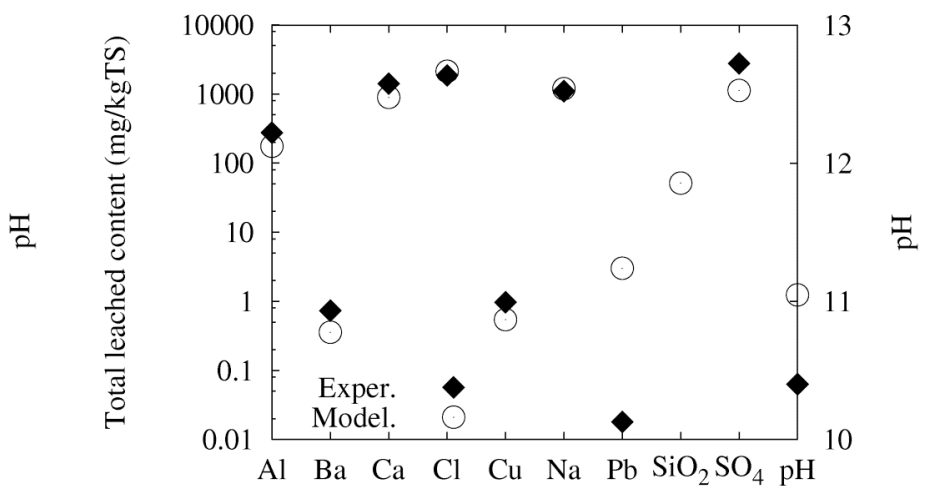

Figure 3 


\section{Hérouville}
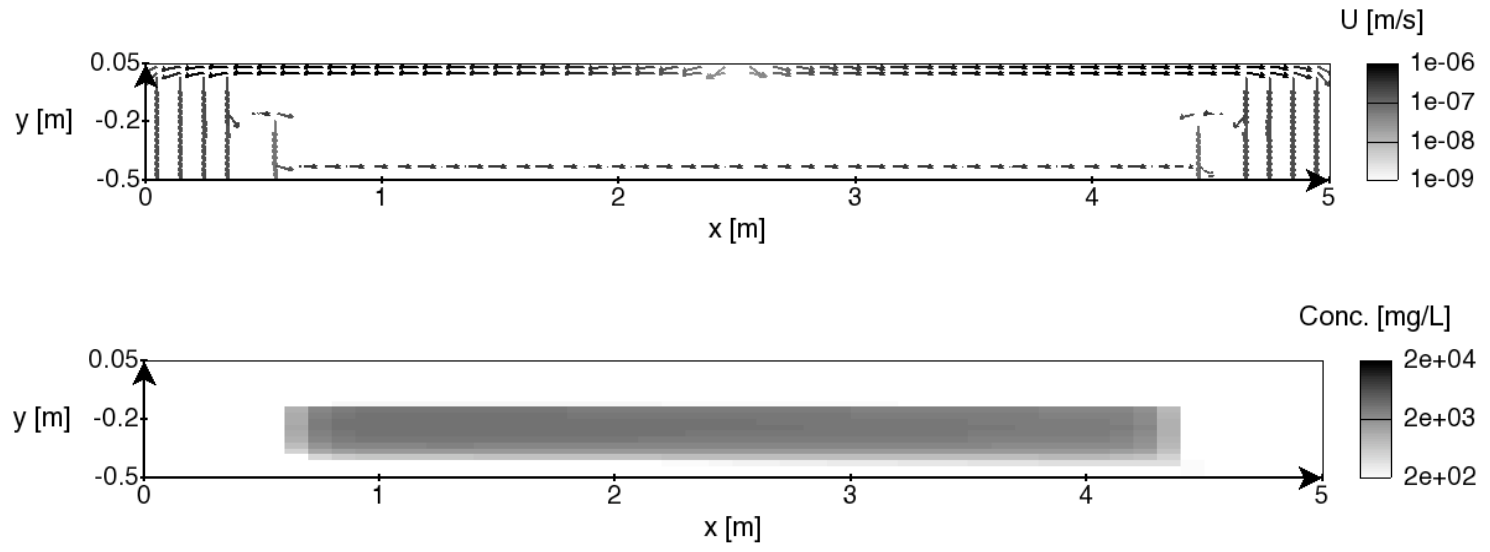

Dåva
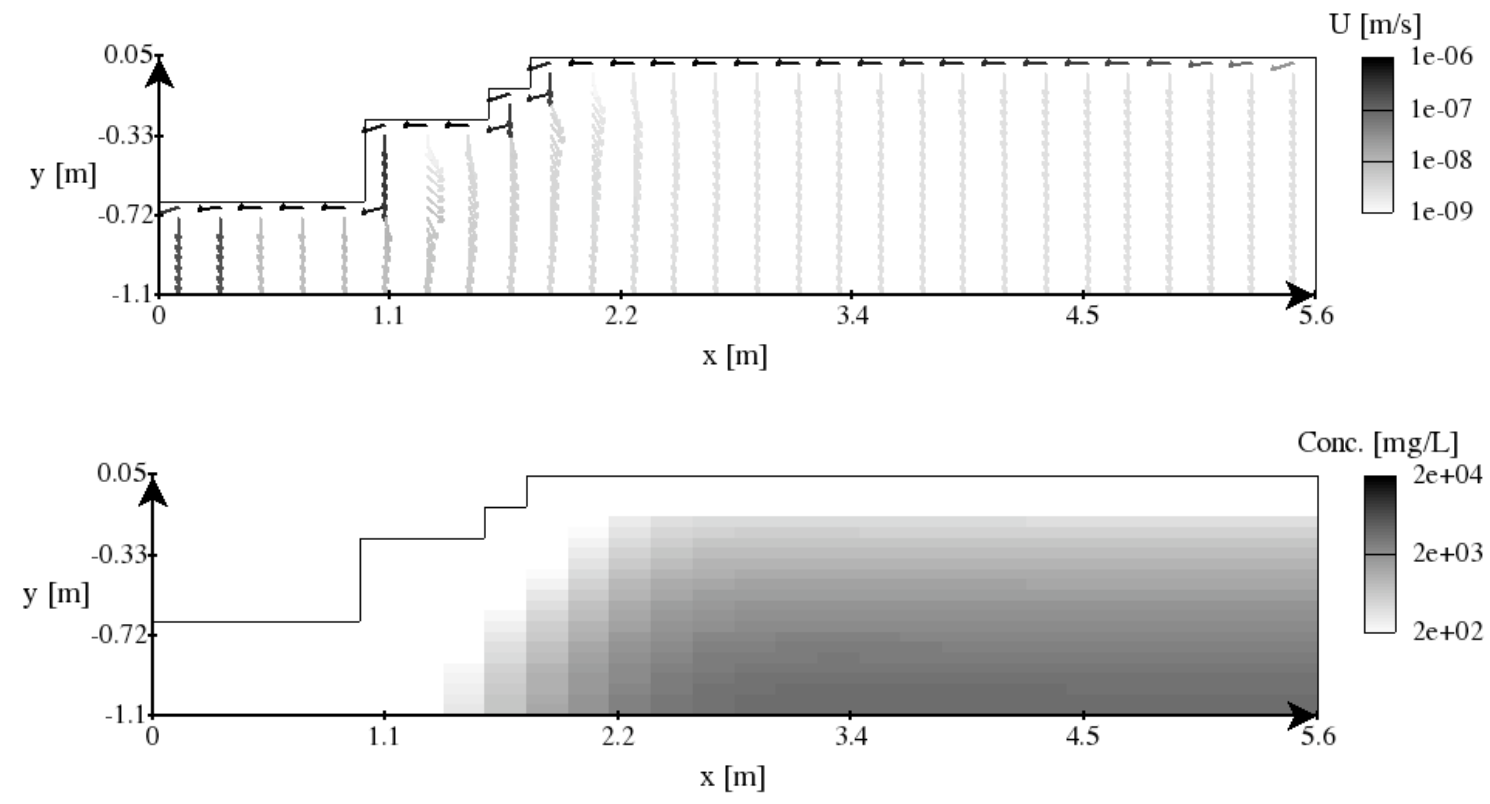

Figure 4 
Hérouville
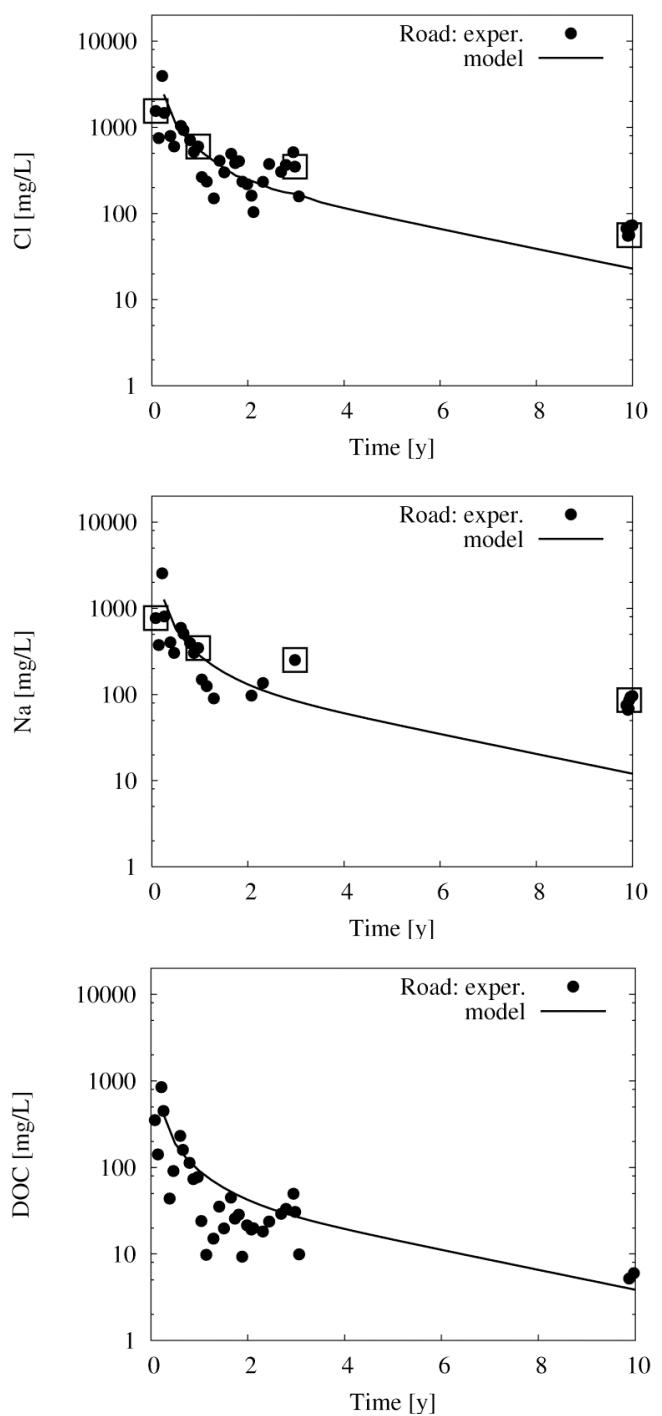

\section{Dåva}
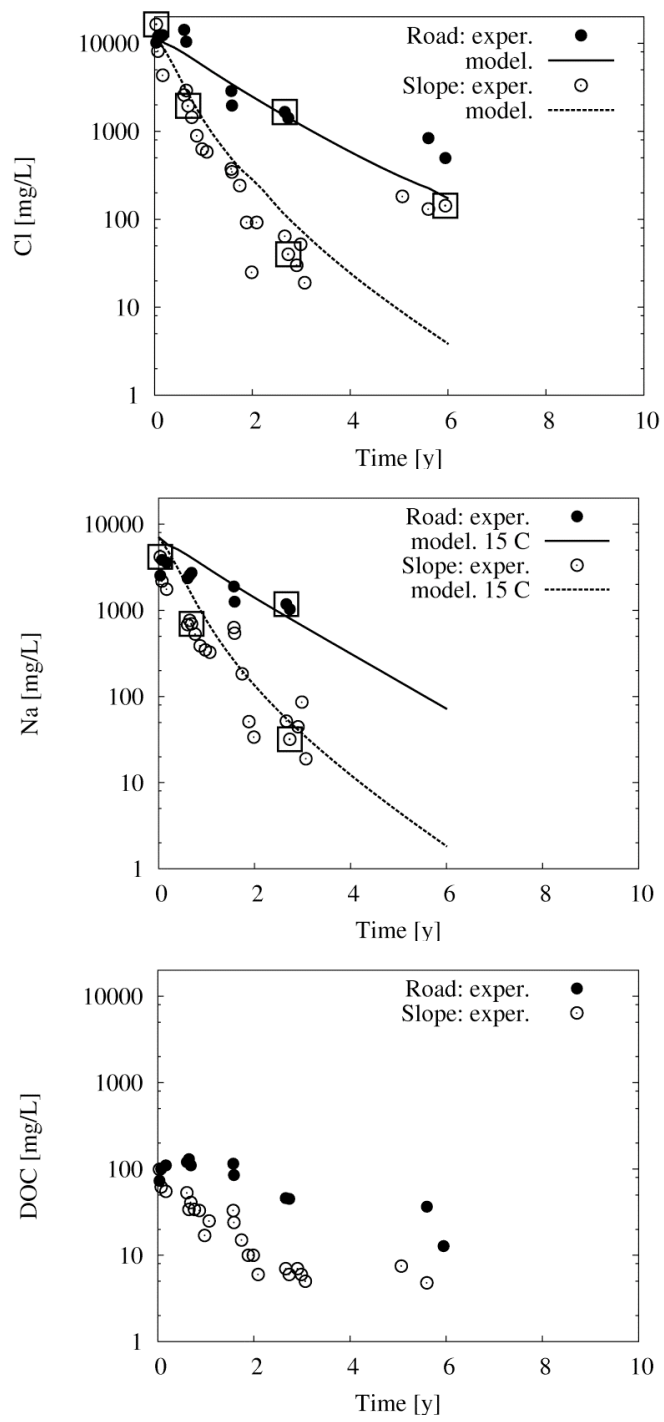

Figure 5 
Hérouville

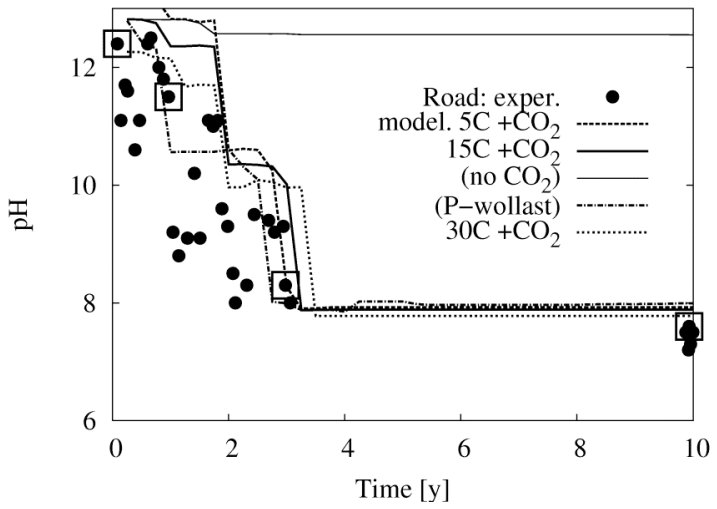

Dåva

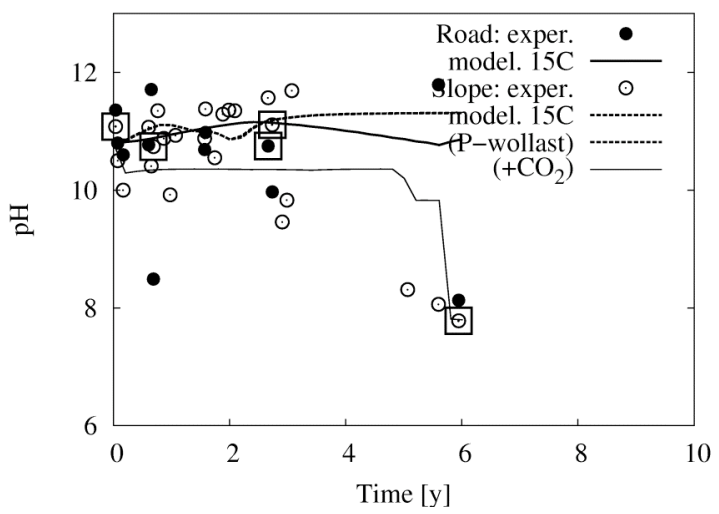

Figure 6 
Hérouville
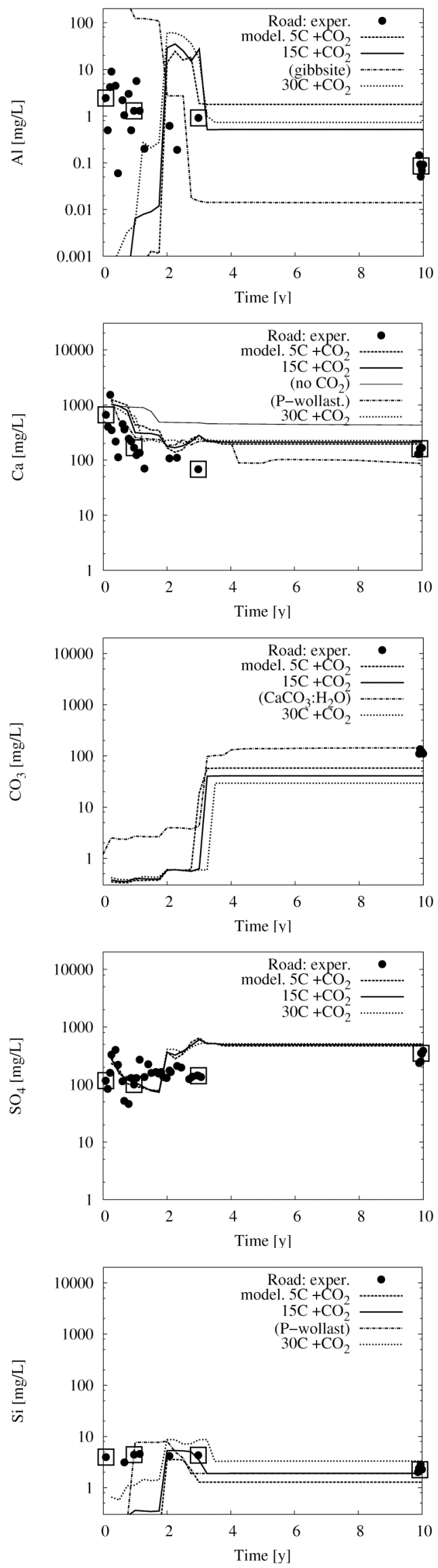

Dåva
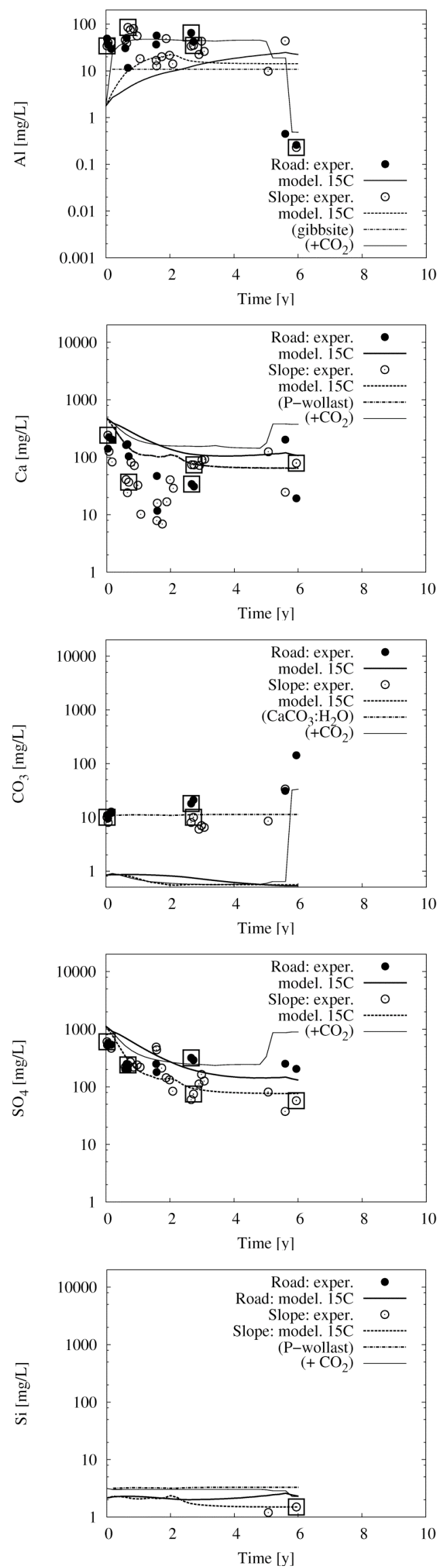

Figure 7 

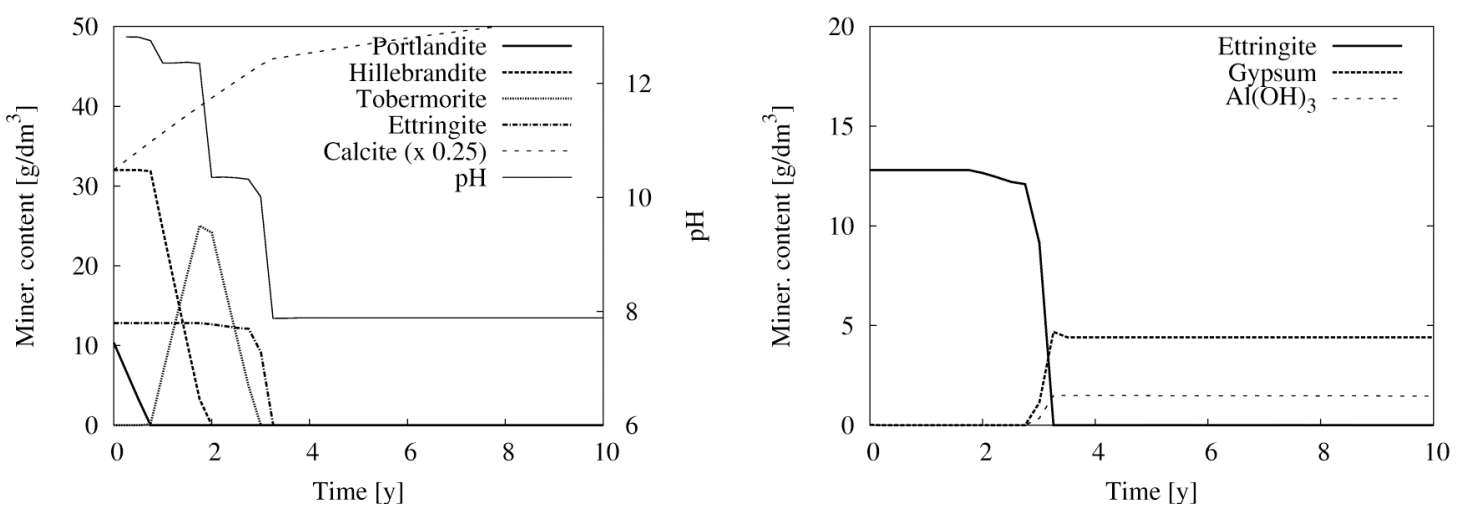

Figure 8 


\section{Hérouville}
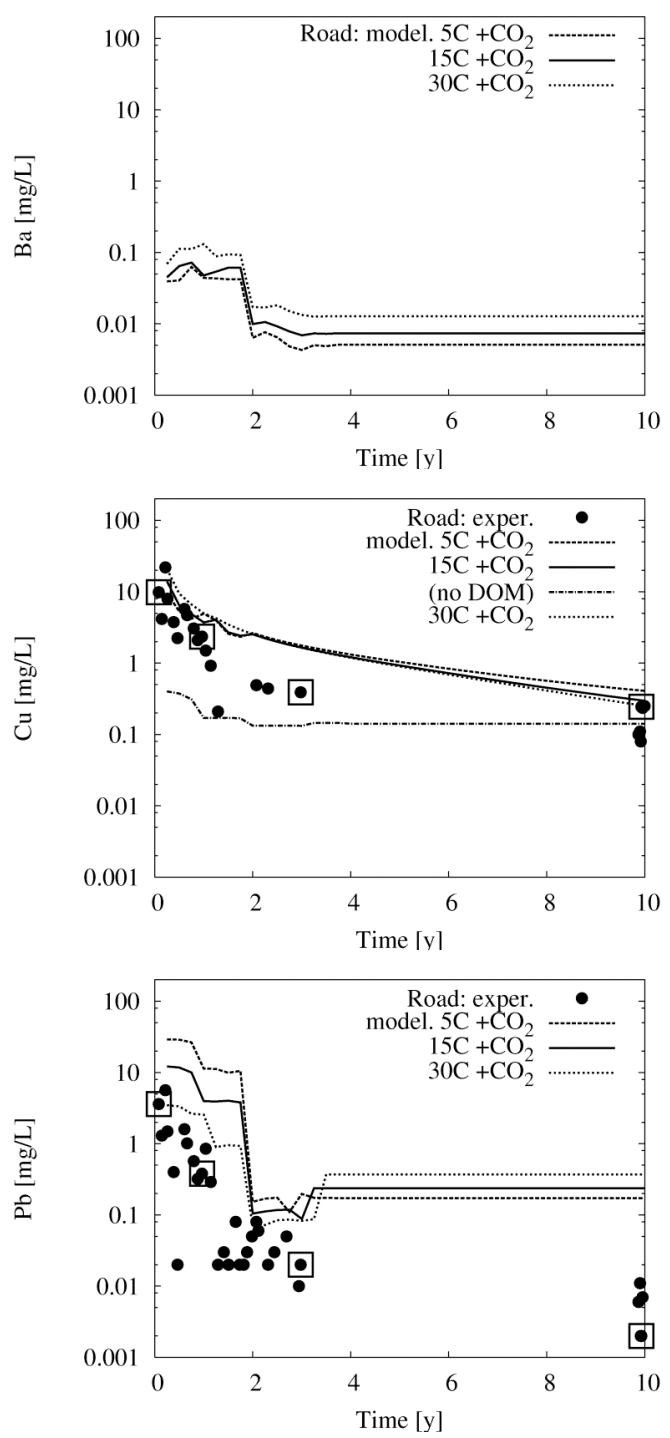

\section{Dåva}
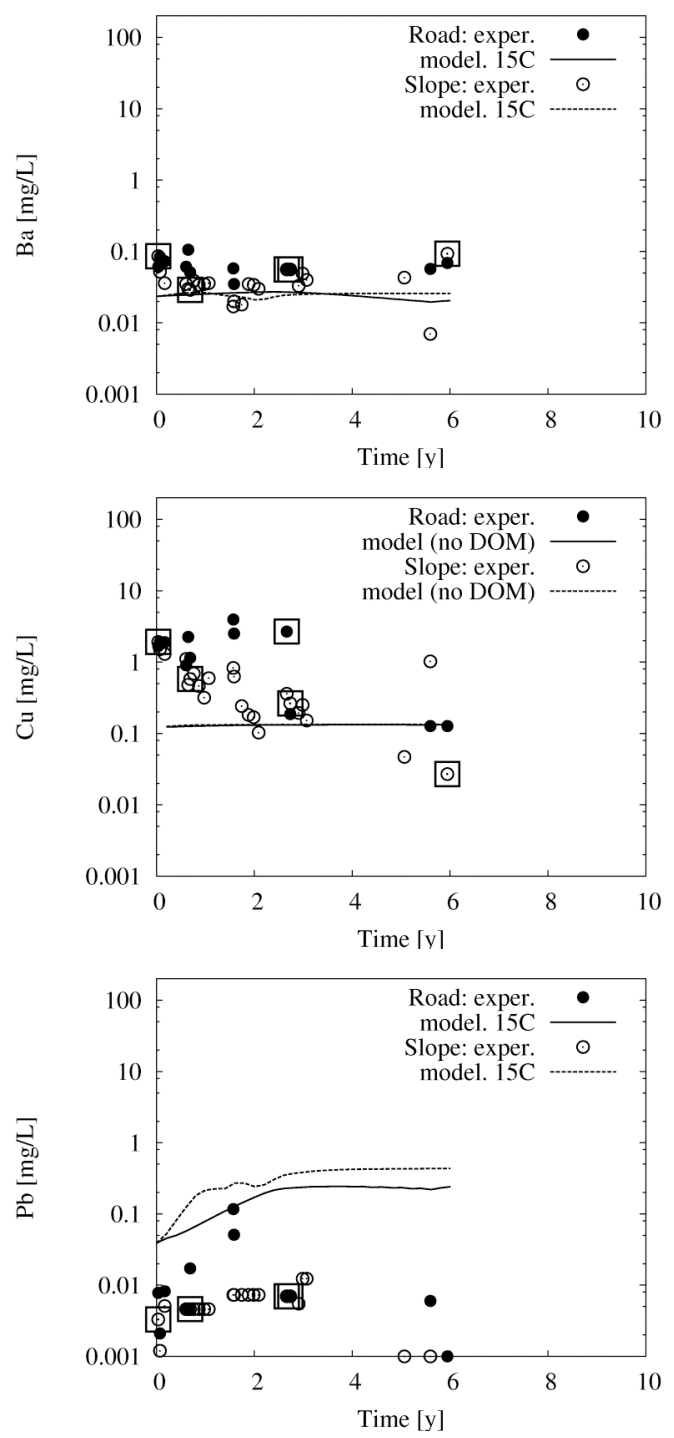

Figure 9 